\title{
BIBLIJNE MEGIDDO W ŚWIETLE REZULTATÓW BADAŃ ARCHEOLOGICZNYCH
}

\section{Położenie i środowisko naturalne Megiddo}

Megiddo było jednym z najważniejszych miast kananejskich w północnej części Palestyny, ${ }^{1}$ położonym w samym sercu Doliny Jezreel (Ezdrelon). Dziś wysokie na 167 m n.p.m. (i wznoszące się ok. $70 \mathrm{~m}$ ponad dolinę) wzgórze Tel Megiddo ${ }^{2}$ jest Parkiem Narodowym i znajduje się na liście światowego dziedzictwa kultury UNESCO. Położone w Dolnej Galilei, po północno-wschodniej stronie ma Nazaret i Górę Tabor, po stronie północno-zachodniej zaś - Karmel i Hajfę. Na południe od Megiddo rozciągają się wzgórza Samarii, a dalej na wschód - Góra Gilboa (gdzie według Biblii zginął Saul) i Bet-Szean (Scytopolis) z dostępem do Doliny Jordanu. David Ussishkin, wieloletni dyrektor ekspedycji archeologicznej prowadzącej tam badania, wskazuje trzy czynniki, które przyczyniły się do niezwykłego znaczenia i dobrobytu Megiddo w okresie biblijnym. Po pierwsze, dwa pobliskie źródła zapewniały odpowiednią ilość wody, wystarczającą do zaspokojenia potrzeb miejscowej populacji. Po drugie, lokalizacja tego miejsca na skraju bardzo żyznej doliny

1 Nazwa „Palestyna” jako oznaczenie regionu geograficznego.

2 Określenia tell będę używać jako pojęcia z dziedziny archeologii, oznaczającego „wzgórze, które powstało w sposób sztuczny, dzięki nawarstwieniu się jednego po drugim - kolejnych osiedlisk ludzkich"; M. M a j e w s k i, Archeologia biblijna, Kraków 2014, s.10. W obecnie używanej nazwie własnej tego miejsca występuje słowo tel (Tel Megiddo), którego będę używać w tym znaczeniu. 
umożliwiała dostęp do obszaru nadającego się do uprawy. Po trzecie (i szczególnie ważne), miasto położone było przy Via Maris - jednym z głównych międzynarodowych szlaków wojskowych i handlowych starożytnego Bliskiego Wschodu, który łączył Egipt z Syrią, Anatolią i Mezopotamią. ${ }^{3}$ Megiddo kontrolowało fragment tej drogi - wąski przesmyk prowadzący do Doliny Jizreel. Ze względu na położenie geograficzne oraz na żyzną i dobrze nawodnioną ziemię, dolina ta przyciągała ludzi już od epoki paleolitu. ${ }^{4}$ Badania archeologiczne wykazały, że Tel Megiddo było zamieszkane w sposób niemal ciągły przez ponad sześć tysiącleci - od przedceramicznego neolitu po okres perski. ${ }^{5} \mathrm{Na}$ przestrzeni setek lat kolejne osady były wznoszone na ruinach poprzednich miast, tworząc niezrównane dziedzictwo archeologiczne, obejmujące monumentalne świątynie, pałace, potężne fortyfikacje i znakomicie zaprojektowane systemy wodne. Strategiczna lokalizacja sprawiła, że Megiddo było miejscem wielu decydujących starć, począwszy od starożytności aż po XX w. naszej ery. Eric H. Cline w książce poświęconej tej tematyce wymienia aż trzydzieści pięć stoczonych tu na przestrzeni tysiącleci bitew, których uczestnikami byli władcy Egiptu (Pepi I, Totmes III, Amenhotep II, Szeszonk I, Necho II), Kananejczycy i Filistyni, Madianici, Amalekici, Izraelici i Judejczycy, Hasmoneusze, władcy hellenistyczni, Rzymianie, Bizantyjczycy, Arabowie, krzyżowcy, Mongołowie, mamelucy, Napoleon, Turcy Osmańscy, Niemcy, wojska brytyjskie i wreszcie współczesne izraelskie i arabskie siły zbrojne. ${ }^{6}$ Można zatem powiedzieć, że okolice Megiddo stały się miejscem bitwy (polem bitewnym) par excellence.

3 D. U s s i s h k i n, Megiddo-Armageddon. The Story of the Canaanite and Israelite City, Jerusalem 2018, s. 9

4 M. J. A d a m s, J. D a v i d, R. H o m s h e r, M.E. C o h e n, The Rise of a Complex Society: New Evidence from Tel Megiddo East, Near Eastern Archaeology 77(2014) nr 1, s. 31.

5 D. Us s is h k i n, Megiddo-Armageddon, s. 15.

6 E. H. C 1 i n e, The Battles of Armageddon: Megiddo and the Jezreel Valley from the Bronze Age to the Nuclear Age, University of Michigan, Michigan 2002, s. 1-3. 


\section{Etymologia i znaczenie nazwy „Megiddo”}

Etymologia nazwy „Megiddo” jest niejasna. ${ }^{7}$ Niektórzy autorzy $^{8}$ wywodzą ją od czasownika דז oznaczającego ,nastawać (na kogoś)”, „,zyhać”, ale też „zbierać się”, „nacinać (sobie skórę na znak żałoby)". ${ }^{10}$ To ostatnie znaczenie wiąże się z zakazem samookaleczania w akcie kultu: ${ }^{11}$ „Jesteście synami Pana, waszego Boga, nie czyńcie po umarłym nacięć [תתְְ] na sobie i nie czyńcie sobie łysiny nad czołem” (Pwt 14,1); „Wołali więc głośno i według swojego

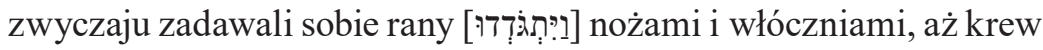
po nich spływała" (1Krl 18,28). Obydwa passusy stanowią odniesienie do praktyk kultowych związanych z cyklem umierania i odradzania się Baala uosabiającego zamierającą i budzącą się do życia przyrodę, ${ }^{12}$ fragment Pierwszej Księgi Królewskiej opisuje zachowanie kapłanów Baala podczas zwycięskiego pojedynku, jaki na górze Karmel stoczył z nimi prorok Eliasz. Niektórzy autorzy zwracają uwagę na możliwość utożsamienia Góry Megiddo z Karmelem. Może więc w nazwie „Megiddo" przetrwała pamięć o praktykowaniu w tym miejscu kultu Baala lub innego bóstwa?

Inne interpretacje nazwy „Megiddo” opierają się na pochodnych czasownika דזג. Zודג Zalicza się do nich rzeczownik thaczony

7 Hasło Megiddo w: F. B r o w n, R. D r i ve r, Ch. B rig g s, The Brown-Driver-Briggs Hebrew and English Lexicon, Hendrickson Pub. 1996.

8 Hasło Megiddo w: Holy Bible: The New Open Bible. New American Standard Bible. Study Edition, Thomas Nelson Inc. 1990.

9 Ps 94,21: „Nastają [יגוֹז [יגוּ] na sprawiedliwego i krew niewinną potępiają” - Biblia Warszawska; „Choć czyhają [יגוֹ krew niewinną" - Biblia Tysiąclecia.

${ }^{10}$ P. B r i k s, Podręczny słownik hebrajsko-polski i aramejsko-polski Starego Testamentu, Warszawa $2000^{3}$, s. 71.

${ }_{11}$ Publikacja R. L. Harris, G. L. A r cher j r., B. Waltke, Theological Wordbook of the Old Testament, Moody Publishers 2003 podaje, że w dziewięciu na jedenaście wystąpień w Biblii, czasownik דדג odnosi się do zakazanego samookaleczania się w akcie kultu.

12 Na ten temat Ł. To b o ł a, Cykl Baala z Ugarit, Kraków 2008. 
jako „hufiec”, „,horda”, „agresor”, ${ }^{13}$ który może też oznaczać „,bandę łupieżców", także w znaczeniu najeźdźców lub grupy oddzielonej od społeczności $(1 \mathrm{Sm} 30,8 ; 1 \mathrm{Krl} 11,24)$. Słowo to oznaczało również, według 1Krn 7,4, należące do potomków Issachara ,zbrojne oddziały bojowe” (Biblia Warszawska) lub „hufce zbrojne” (Biblia Tysiąclecia). ${ }^{14}$ Dlatego niektórzy badacze wiążą nazwę "Megiddo" z tymi znaczeniami, np. w słowniku J. Stronga znajdujemy jej wyjaśnienie jako miejsca spotkania lub miejsca tłumów. ${ }^{15}$ Przeciwnicy takiej interpretacji podkreślają jednak, że czasownik דזג oznacza aktywność, a nie bierne gromadzenie się, zaś pierwsza litera nazwy „Megiddo" (מ) wskazuje na działanie. Zatem nazwa ta powinna być objaśniana za pomocą „dynamicznego” słownictwa (jak np. związane z inwazją czasowniki „najechać”, ,wtargnąć”," niepokoić” itp.). ${ }^{16}$

\section{Megiddo w Biblii}

W Biblii Hebrajskiej Megiddo (מְגָּ pojawia się w narracji odnoszącej się do czasów sędziów (generalnie datowanych na XII-XI w. p.n.e. $)^{17}$ i wzmiankowane jest w sumie kilkunastokrotnie. ${ }^{18}$ Po raz

13 P. B r i k s, Podręczny słownik hebrajsko-polski i aramejsko-polski Starego Testamentu, s. 71.

14 Inną pochodną czasownika דדג jest identyczny z przedstawionym rzeczownik דודג i jego żeński odpowiednik גדודה, które oznaczają „,bruzdę”, ,skibę”” lub „,cięcie”. Za pochodną czasownika דדג można uznać także rzeczownik דגדודה tłumaczony jako „szczęście”; zob. tamże.

15 http://biblia-online.pl/Slownik/Biblijny/JamesStrongHebrew/Strong/H4023 (dostęp: 3 III 2019). Strong także wyprowadza nazwę „Megiddo” od czasownika דדג, który tłumaczy jako „przeniknąć”, ,przeciąć”, ,zaatakować”, „,najechać”, „pokroić”, „pociąć się”, „gromadzić” wojsko lub tłum, „spotykać się”.

16 Hasło Megiddo w: http://www.abarim-publications.com/Meaning/Megiddo. html\#anc-2 (dostęp: 3 III 2019).

17 I. F i n k e l s t e i n, D. U s s i s h k i n, Back to Megiddo, Biblical Archaeology Review 20(1994) nr 1, s. 26-33, 36-37, 39-43.

18 Według Biblii Warszawskiej: Joz 12,21: „Król Taanachu jeden; król Megiddo

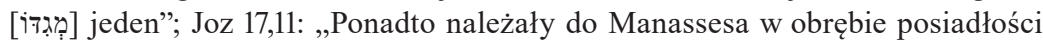
Issachara i Aszera Bet-Szean i jego osady, Jibleam i jego osady, mieszkańcy Dor 
pierwszy wymienia się je wśród nazw ziem, których królów, „wytracił Jozue i synowie izraelscy po drugiej stronie Jordanu na zachodzie" (Joz 12,7). Dalej Biblia podaje, że Megiddo leżało na terytorium Issachara, ale było jednym z miast przypisanych do Manassesa (Joz 17,11; 1Krn 7,29). Jednak, jak można przypuszczać na podstawie przekazu biblijnego, nie było w pełni zajęte przez Izraelitów aż do czasów Salomona (1Krl 4,12; 9,15). Księga Sędziów opisuje znaczące zwycięstwo, jakie w okolicy Megiddo i Góry Tabor odniósł Barak (syna Abinoama z Kedesz - Naftali) nad królem Hazoru, którego generał, Sisera, przewodził wrogiej armii. Barak zwołał wojowników z północnych plemion i za namową prorokini Debory zaatakował Kananejczyków

i jego osady, i mieszkańcy En-Dor i jego osady, Taanach i jego osady, mieszkańcy Megiddo i jego osady, trzy górzyste okręgi”; Sdz 1,27: „Manasses zaś nie posiadł Bet-Szean i jego osad ani Taanak i jego osad, ani nie wypędził mieszkańców Dor i jego osad, ani mieszkańców Jibleam i jego osad, ani mieszkańców Megiddo i jego osad. Kananejczycy więc zdołali utrzymać się w tej ziemi”; Sdz 5,19: „Przyszli królowie i walczyli, Walczyli wówczas królowie kananejscy W Taanak, nad wodami Megiddo, Lecz łupu w srebrze nie wzięli”; $1 \mathrm{Krl}$ 4,12: „Baana, syn Achiluda, miał pod sobą Taanak, Megiddo i cały Bet-Szean tuż przy Sartan pod Jezreelem, od Bet-Szean po Abel-Mechola i poza Jokneam”; 1Krl 9,15: „Tak się zaś miała rzecz z pańszczyzną, jaką wprowadził król Salomon, budując przybytek Pana i swój pałac, i twierdzę Millo, i mury Jeruzalemu, i warownie Chasor, Megiddo i Gezer"; 2Krl 9,27: „Gdy to zobaczył Achazjasz, król judzki, zaczął uciekać w stronę Bet-Haggan. Jehu jednak rzucił się za nim w pościg, wołając: Również tego ubijcie! I raniono go na rydwanie, na wzniesieniu Gur, które jest przy Jibleam. Uciekł on do Megiddo i tam umarł”; 2Krl 23,29: „Za jego czasów wyruszył faraon Necho, król egipski, przeciwko królowi asyryjskiemu nad rzekę Eufrat. Gdy król Jozjasz wyprawił się, aby się z nim potykać, ten, gdy go zobaczył, pozbawił go życia pod Megiddo”; $2 \mathrm{Krl}$ 23,30: „Dworzanie jego wywieźli go na wozie już umarłego z Megiddo i sprowadzili do Jeruzalemu, i pochowali w jego grobie. Prosty lud zaś wziął Jehoachaza, syna Jozjasza, i namaściwszy go, obwołali go królem w miejsce Jego ojca”; 1Krn 7,29: „W kierunku siedzib Manassesytów Bet-Szean z jego miasteczkami, Taanak z jego miasteczkami. Megiddo z jego miasteczkami i Dor z jego miasteczkami. W nich mieszkali potomkowie Józefa, syna Izraela”; 2Krn 35,22: „Lecz Jozjasz nie zaniechał go, owszem szykował się, aby się z nim rozprawić, nie słuchając słów Necha, które jednak pochodziły z ust Bożych, i ruszył do bitwy na równinie Megiddo”; Za 12,11: „W owym dniu będzie w Jeruzalemie wielkie narzekanie, jak narzekania o Hadad-Rimmon na równinie Megiddo". 
na wielkiej równinie. Armia Sisery doznała całkowitej klęski „nad wodami Megiddo" (Sdz 5,21) i została pochłonięta przez Kiszon (Sdz 4,5 - 5,21).

Według przekazu biblijnego Megiddo przeżywało okres świetności w czasach Salomona, gdy należało do najbardziej znaczących ośrodków jego królestwa. Pierwsza Księga Królewska podaje, że miasto było wtedy siedzibą okręgu administracyjnego: „Salomon miał dwunastu namiestników nad całym Izraelem; oni zaopatrywali króla i jego dwór w żywność; co miesiąc w ciągu roku miał inny zaopatrywać” (1Krl 4,7); „Baana, syn Achiluda, miał pod sobą Taanak, Megiddo i cały Bet-Szean" (1Krl 4,12). O znaczeniu Megiddo w tym okresie świadczy fakt, że zostało wymienione jako jedno z miast, które król kazał ufortyfikować (1Krl 9,15).

Kolejne narracje biblijne związane z Megiddo dotyczą tragicznej śmierci w tym mieście dwóch królów judzkich. Pierwszy z nich, Ochozjasz (Achazjasz), ofiara rewolty Jehu, śmiertelnie raniony na wzniesieniu Gur, uciekł do Megiddo, gdzie zmarł (2Krl 9,27; 841 r. p.n.e. ${ }^{19}$ ). Ponad dwieście lat później (609 r. p.n.e.) zginął w Megiddo inny król judzki, Jozjasz. Odnoszący się do tego wydarzenia przekaz biblijny nie jest jednoznaczny. Druga Księga Królewska opisuje je następująco: „Wyruszył faraon Necho, król egipski, przeciwko królowi asyryjskiemu nad rzekę Eufrat. Gdy król Jozjasz wyprawił się, aby się z nim potykać, ten, gdy go zobaczył, pozbawił go życia pod Megiddo (2Krl 23,29; także 2Krn 35,20 - 35,24, która przedstawia to wydarzenie trochę inaczej). ${ }^{20}$ Żałoba po śmierci tego władcy była tak powszechna i pełna żalu, że Megiddo stało się niemal przysłowiowym miejscem kojarzącym się z tragiczną śmiercią. Aluzję do tego, co działo się po zabójstwie Jozjasza, zawiera ostatnia wzmianka o Megiddo w Biblii Hebrajskiej znajdująca się w Księdze Zachariasza 12,11: „W owym dniu będzie w Jeruzalemie wielkie narzekanie,

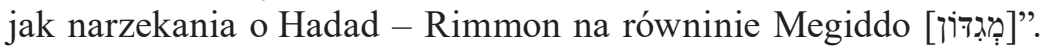

19 M. L i v e r a n i, Nie tylko Biblia. Historia starożytnego Izraela, tłum. J. P u c h a 1 s k i, Warszawa 2010, s. 145.

20 Tamże, s. 194. 
„Równina Megiddo" stała się tu poetyckim wyrazem najgłębszego żalu i największej rozpaczy. ${ }^{21}$

Megiddo zajmuje ważne miejsce w tradycji chrześcijańskiej, ${ }^{22}$ opartej na Apokalipsie św. Jana. Zawierający odpowiednią nazwę fragment Ap 16,16 brzmi następująco: „I zgromadził ich na miejscu, które po hebrajsku nazywa się Armagedon" ( $\alpha \rho \mu \alpha \gamma \varepsilon \delta \delta \omega v)$. Nazwa właściwie oznacza tutaj „góra Megiddo" (Har Megiddon), ${ }^{23}$ symbolicznie wyznaczając miejsce rozstrzygającego starcia między siłami dobra i zła i ostatecznego triumfu Chrystusa nad Antychrystem. Nie jest zaskoczeniem dokonany przez autora Apokalipsy wybór przestrzeni, w której dojdzie do decydującej bitwy. Ma się ona rozegrać na polu bitwy par excellence, na równinie Jezreel (Esdrelon), która zasłynęła z wielkich starć opisanych w Starym Testamencie. Dlatego Har Megiddo oznacza w Apokalipsie miejsce wielkiej rzezi i straszliwej zemsty, której doznają grzesznicy. Tradycja chrześcijańska związana z tym miejscem jest bardzo wczesna. Potwierdza to niedawne odkrycie dokonane podczas prac wykopaliskowych w Kefar 'Othnay, na stanowisku z okresu rzymskiego, położonym w bliskiej odległości od Tel Megiddo, na południe od wzniesienia. Wykopaliska odsłoniły tam pochodzącą z III w. chrześcijańską salę modlitewną z piękną mozaiką na podłodze, zawierającą m.in. figury geometryczne, znak

${ }^{21}$ Hasło Megiddo w: International Standard Bible Encyclopedia Online; https:// www.internationalstandardbible.com/M/megiddo-megiddon.html (dostęp: 21 II 2019); E. H. C 1 i n e, Why Megiddo? Bible Review 16(2000) nr 3, s. 22-24, 26-31.

22 Tamże, s. 177-187.

23 D. Us s is h k i n, Megiddo - Armageddon, s. 27. Warto zwrócić uwagę na propozycje wyjaśnienia tej nazwy w Apokalipsie przez powiązanie jej z pobliską Górą Karmel, gdzie Eliasz pokonał proroków Baala (co oznaczało zwycięstwo Jahwe nad złymi mocami) oraz na inne możliwości interpretacji nazwy Har Megiddo: odniesienie do Góry Syjon (w literaturze apokaliptycznej bywa ona miejscem walki Boga z siłami zła), do Jerozolimy, a także do kraju lub miasta Megiddo czy wreszcie - do ,góry narad” - zgromadzenia bogów na dalekiej północy - Iz 14, 13: „A przecież to ty mawiałeś w swoim sercu: Wstąpię na niebiosa, swój tron wyniosę

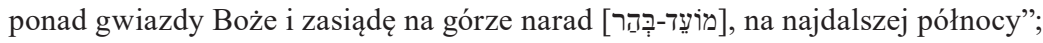
por. J. K r a š o v e c, The Transformation of Biblical Proper Names, New York-London 2010, s. 79. 
ryby oraz najstarszy z dotąd odnalezionych na terenie Izraela napis wzmiankujący Chrystusa: „Bóg Jezus Chrystus”. ${ }^{24}$

\section{Megiddo w źródłach pozabiblijnych}

Poza narracją biblijną Megiddo pojawia się głównie w źródłach egipskich. Najstarsza wzmianka znajduje się na VI pylonie świątyni Amona w Karnaku, na którym Totmes III kazał przedstawić swoje zwycięstwo w bitwie z Kananejczykami. ${ }^{25}$ Faraon ten podczas pierwszych dwudziestu lat swego samodzielnego panowania przeprowadził siedemnaście kampanii wojennych do zachodniej Azji. Pierwszym i zapewne najważniejszym starciem wojsk Totmesa w czasie tych wypraw okazała się bitwa pod Megiddo (ok. 1457 r. p.n.e..) Zaprezentowana szczegółowo na reliefie historia kampanii faraona była badana i dyskutowana przez wielu uczonych, jednak okazała się niełatwa do zrekonstruowania wydarzeń. ${ }^{26}$ Zgodnie z inskrypcją wojska egipskie, W nieznanej liczbie, ${ }^{27}$ dowodzone osobiście przez Totmesa III, przemaszerowały przez północny Synaj i Gazę, a następnie posuwały się wzdłuż Via Maris. Gdy Egipcjanie dotarli do północnej części dzisiejszej równiny Szaron, dowódcy zakomunikowali faraonowi, że wojska kananejskie, dowodzone przez króla Kadesz, zgromadziły się pod Megiddo, zagrażając hegemonii egipskiej w tym regionie.

24 Y. Te p p e r, L. D i S e g n i, A Christian Prayer Hall of the Third Century CE at Kefar 'Othnay (Legio). Excavation at the Megiddo Prison, Jerusalem 2006, s. 36; D. U s s i s h k i n, Megiddo-Armageddon, s. 27; 441-442.

25 N. G r i m a 1, Dzieje starożytnego Egiptu, tłum. A. Ł u k a s z e w i c z, Warszawa 2005, s. 314.

26 Z obszernej dyskusji warto przytoczyć ostatnie publikacje: R. D r e w s, The End of the Bronze Age. Changes In Warfare and Catastrophe ca. 1200 B.C., Princeton 1993, s. 113-134; D. B. R e d for d, The Wars in Syria and Palestine of Thutmose III, Leiden-Boston 2003; A. J. S p a 1 i n g e r, War in Ancient Egypt: The New Kingdom, Malden 2005, s. 83-100; D. U s s i s h k i n, Megiddo-Armageddon, s. 222; D. B e n - T o r, Pharaoh in Canaan. The Untold Story, The Israel Museum, Jerusalem 2016, s. 51-53.

27 D. B. Red ford, The Wars in Syria and Palestine of Thutmose III, s. 36 podaje liczbę ok. 10 tys. 
Szczegółowy opis wydarzeń pokazuje sprytny manewr wojsk egipskich, dzięki któremu odniosły one wspaniałe zwycięstwo, a po siedmiomiesięcznym oblężeniu zdobyły także samo Megiddo. Inskrypcja przedstawia imponującą listę zagarniętych przez Egipcjan łupów, co świadczy o zamożności zdobytego miasta. ${ }^{28}$ Zwycięstwo Totmesa skutkowało objęciem Kanaanu egipską kontrolą - miejscowi władcy stali się wasalami faraona, a samo Megiddo stało się egipską twierdzą.

Papirus z okresu panowania Amenofisa II (II połowa XV w. p.n.e., przechowywany w Państwowym Muzeum Ermitażu w St. Petersburgu $^{29}$ ) wśród kananejskich maryannu $u^{30}$ wysłanych do Egiptu w osiemnastym roku panowania tego faraona wymienia też posłańca z Megiddo. Taka informacja pozwala przypuszczać, że było ono wówczas jednym z najważniejszych miast-państw północnego Kanaanu. ${ }^{31}$ Jego znaczenie w tym okresie poświadczają kolejne wzmianki, zawarte $\mathrm{w}$ pochodzących z połowy XIV w. p.n.e., zapisanych w języku akadyjskim tekstach tabliczek z kananejskiego Tanak, położonego na południowym krańcu Doliny Jezreel..$^{32}$ Jednak jednym

28 Wśród łupów, prócz żywych jeńców, znajdowały się np. odcięte dłonie zabitych wojowników, konie (w tym ogiery i źrebięta), ceremonialne rydwany władcy Megiddo oraz rydwany innych władców kananejskich, pancerze, łuki, namioty, a także kozy, owce i krowy; por. D. U s s i s h k i n, Megiddo-Armageddon, s. 233-234.

29 Papyrus Petersburg 1116A.

30 Termin akadyjski oznaczający walczącą na wozach wyspecjalizowaną wojskową arystokrację, por. M. L i v e r a n i, Nie tylko Biblia. Historia starożytnego Izraela, s. 34, 56.

31 D. U s s is h k i n, Megiddo-Armageddon, s. 237; Y. G o r e n, I. F i n k e l$\mathrm{s}$ t e i n, N. N a' a m a n, Inscribed in Clay. Provenance Study of the Amarna Letters and Other Ancient Near Eastern Texts, Tel Aviv 2004, s. 247; N. N a' a m a n, Canaan in the Second Millenium B.C.E., Winona Lake 2005, s. 161, D. B. R e d fo r d, The coregency of Tuthmosis III and Amenophis II, Journal of Egyptian Archaeology 51/1965, s.107-122.

32 W. Hor ow it z, T. O s h i m a, S. S a n d e r s, A Bibliographical List of Cuneiform Inscriptions from Canaan, Palestine/Philistia, and the Land of Israel, Journal of the American Oriental Society 122(2002) nr 4, s.753-766; A. F. R a i n e y, Verbal Usages in the Taanach Texts, Israel Oriental Studies VII, Tel-Aviv University, Tel-Aviv 1977, s. 33-64; K. v a n d e r To o r n, Cuneiform documents from 
z najważniejszych źródeł dla dziejów Megiddo w okresie późnego brązu są listy z Amarny. ${ }^{33} \mathrm{~W}$ literaturze naukowej listy te oznacza się najczęściej za pomocą skrótu EA (el-Amarna), a ich numerację przyjęto według edycji i tłumaczenia tekstu J. A. Knudtzona. ${ }^{34}$

Syria-Palestine: texts, scribes, and schools, Zeitschrift des Deutschen Palästina-Vereins 116(2000) nr 2, s. 97-113; A. N e g e v, Encyklopedia archeologiczna Ziemi Świętej, tłum. O. Z i e n k i e w i c z, Warszawa 2002, s. 286, 427.

${ }_{33}$ Pod koniec XIX w. w miejscowości Tell el-Amarna w Egipcie, ok. 300 km na południe od Kairu, na stanowisku zawierającym pozostałości Achetaton - stolicy faraona Echnatona, odkryto archiwum kilkuset glinianych tabliczek (część pozyskano od okolicznej ludności). Miasto zostało założone w czwartym roku panowania tego władcy, a opuszczone przez dwór królewski w trzecim roku panowania Tutanchamona, było więc stolicą krótkotrwałą (pełniło tę funkcję kilkanaście lat w II połowy XIV w. p.n.e.). Łącznie obecnie znanych jest ok. 380 tabliczek zapisanych w przeważającej części akadyjskim pismem klinowym. Większość z nich stanowi dyplomatyczną korespondencję egipskiego dworu królewskiego, a mała grupa 32 tabliczek to szkolne teksty używane do nauczania i uczenia się języka akadyjskiego. Większą część listów wysłano do Egiptu z państw zachodnioazjatyckich i wasalnych miast kananejskich. Jedynie 12 tabliczek stanowią listy wysłane z Egiptu do państw Azji Zachodniej. Korespondencja Egiptu z dużymi mocarstwami zawiera 44 listy od (i do) królów Babilonu, Asyrii, Hetytów, Mitanni, Alaszija (Cypru) i Arzawy. Korespondencja wasalna obejmuje listy wysłane od (i do) władców miast-państw będących pod bezpośrednią egipską dominacją, jak Damaszek, Byblos, Hazor, Megiddo, Jerozolima i Aszkelon, lub z królestwznajdujących się poza granicami imperium egipskiego w Azji, takich jak Ugarit, Kadesz i Katna.Chociaż archiwum obejmuje dość krótki czas, od ok. 30. roku panowania Amenhotepa III do 3. roku panowania Tutanchamona (ok. 1360-1334 p.n.e.) i jest stosunkowo niewielkie, to jednak stanowi jedną z najważniejszych kolekcji starożytnych tekstów, ponieważ dostarcza unikalnych i bezcennych informacji dotyczących interakcji dyplomatycznych między Egiptem a innymi państwami Bliskiego Wschodu oraz wiedzy o podziałach terytorialnych i stosunkach politycznych w Kanaanie późnej epoki brązu. Archiwum amarneńskie wskazuje na istnienie w Kanaanie egipskiego aparatu administracyjnego, za pomocą którego faraonowie kontrolowali system zależnych od nich miast-państw; W. L. M or a n, The Amarna Letters, Baltimore-London 1992, EA 242-246, EA 248, EA 365; Y. G o r e n, I. F i n k e 1 s t e i n, N. N a' a m a n, Inscribed in Clay. Provenance Study of the Amarna Letters and Other Ancient Near Eastern Texts, s. 1.

34 J.A. K n u d t z o n, Die El-Amarna-Tafeln I+II, Leipzig 1907; t e n ż e, Die El-Amarna-Tafeln III. Anmerkungen und Register bearbeitet von Weber und E. Ebeling, 
Autorem sześciu listów (EA 242 - 246 oraz EA 365) jest Biridija, który prezentuje się jako „władca Magiddy” w liście EA 242, 3 - 4 i wzmiankuje nazwę swego miasta w trzech innych listach (EA 243, 244, 245). W korespondencji tej Biridija podkreśla swoją lojalność wobec faraona, np. list EA 365 zaczyna następująco: „Do króla, mojego pana i mojego słońca: tak mówi Biridija, wierny sługa króla: U stóp króla, pana mego i mojego słońca, siedmiokrotnie i siedmiokrotnie padam na twarz". W innym liście (EA 243) władca Megiddo prosi o wojskową pomoc $\mathrm{w}$ obawie przed podbiciem swego królestwa przez króla Sychem, Labaju, któremu pomagają habiru. ${ }^{35}$ Autorem kolejnego listu wysłanego z Megiddo (EA 248) jest Jaszdata, władca miasta-państwa, którego tożsamość nie jest jednoznacznie określona, być może były władca Tanak. W swoim liście informuje on faraona, że został ograbiony ze wszystkich swoich rzeczy, wybito mu bydło i wypędzono go z jego miasta, aż znalazł się w Megiddo (którego władcą był Biridija) ${ }^{36}$

Na podstawie korespondencji amarneńskiej można wnioskować, że Megiddo było jednym z największych miast-państw kananejskich, zależnych od Egiptu w późnej epoce brązu. ${ }^{37}$ Tę silną pozycję w regionie miasto zachowało w kolejnym stuleciu, a świadectwem tego mogą być związki z potężnym królestwem Hetytów. Megiddo jest, jak się wydaje, wzmiankowane w pokrytej pismem hetyckim tabliczce, znalezionej w stolicy tego państwa (Hatussa, dziś Boğazköy w Turcji), będącej listem wysłanym do króla Hattusilisa III (połowa

Leipzig 1915. Inne oznaczenia (LA) stosuje w swoim wydaniu M. L i v e r a n i, Le lettere di El-Amarna, t. 1-2, Brescia 1998-1999.

${ }^{35}$ Podaję za Liveranim, że habiru to w późnej epoce brązu ,grupy ludzi - zbiegów odciętych od swego rodzimego środowiska”, „zadłużeni wieśniacy, którym pozostawała jedynie ucieczka w pozbawione kontroli lesiste góry i przedpustynne stepy”; „określenie to wiąże się etymologicznie i semantycznie z najstarszymi świadectwami użycia określenia Hebrajczycy ('ibrî), zanim przyjęło ono wartości etniczne"; M. L i v e r a n i, Nie tylko Biblia. Historia starożytnego Izraela, s. 43.

${ }^{36}$ Y. G o r e n, I. F in ke l s t e i n, N. N a' a m a n, Inscribed in Clay. Provenance Study of the Amarna Letters and Other Ancient Near Eastern Texts, s. 247.

37 D. U s s i s h k i n, Megiddo-Armageddon, s. 238-239. 
XIII w. p.n.e.). ${ }^{38}$ Podczas prac wykopaliskowych w Megiddo odkryto także hetycką pieczęć oraz plakietkę z kości słoniowej, co zdaniem D. Ussishkina świadczy o bliskich relacjach miasta z hetyckim mocarstwem, a zatem potwierdza także znaczenie Megiddo ${ }^{39}$.

Krótka wzmianka o Megiddo występuje w tekście pochodzącym z epoki ramessydzkiej (XIX dynastia, przełom XIII i XII w. p.n.e.) znajdującym się na papirusie Anastasi I: ${ }^{40}$ „W drodze do Megiddo znajduje się przewężenie nękane przez $S z a s u^{41}$ ukrywających się pod krzewami ...". ${ }^{42}$ Informacja ta dowodzi, że miasto nadal było istotnym ośrodkiem w rejonie Doliny Jezreel. Zostawiając na boku owych Szasu, możemy przyjąć, że określenie „droga do Megiddo” wskazuje nań jako ważny punkt docelowy.

Około 925 r. p.n.e. faraon Szeszonk I (biblijny Sziszak) przeprowadził zwycięską kampanię obejmującą swym zasięgiem prawie całą Palestynę, ${ }^{43}$ docierając aż do Megiddo. Informacje o tej wyprawie czerpiemy z Biblii (1Krl 14,25-28; 2Krn 12,2-12), ze steli wzniesionej przez Szeszonka I w Megiddo oraz z inskrypcji wyrytej na rozkaz faraona na murze zewnętrznym południowego portalu świątyni Amona w Karnaku. ${ }^{44}$ Relief ten przedstawia króla, który w geście triumfu wymierza maczugą ciosy spętanym jeńcom symbolizującym

38 I. S i n ge r, Megiddo mentioned In a Letter from Boğazköy, w: E. N e u, C. R ü s t e r, Documentum Asiae Minoris Antiquae. Festschrift für Heinrich Otten zum 75. Geburstag, Wiesbaden 1988, s. 327-332.

39 D. U s s i s h k i n, Megiddo-Armageddon, s. 239.

40 Obecnie przechowywany w British Museum http://bit.ly/ct-3-19-1 (dostęp: 24 II 2019); tekst wydany m.in. przez A. H. G a r d i n e r, Egyptian Hieratic Texts Series I: Literary Texts of the New Kingdom, cz. I, Leipzig 1911.

${ }^{41}$ Szasu (nazwa egipska) - w późnej epoce brązu byli nomadami, działającymi na pograniczu pustyni i stepu oraz na wyżynach centralnych Kanaanu. Byli uważani za niebezpiecznych, władcy kananejskich miast-państw nie mieli nad nimi kontroli (ale byli wynajmowani jako przewodnicy lub eskorta). W okresach głodu szukali schronienia w Egipcie; por. M. L i v e r a n i, Nie tylko Biblia. Historia starożytnego Izraela, s. 40-41.

42 Cyt. za: tamże, s. 40.

43 Używam tej nazwy w znaczeniu geograficznym.

44 D. Us s is h k i n, Megiddo-Armageddon, s. 326. 
pokonane miasta. ${ }^{45}$ Jeńcy przedstawieni zostali z małymi, przypominającymi kartusz owalami (lub pierścieniami); w każdym z nich znajduje się hieroglificzny zapis nazwy miejsca, które Szeszonk prawdopodobnie podbił w swoich kampaniach. Wśród tych miast wymienione zostało Megiddo. Informacje zawarte w inskrypcji znalazły potwierdzenie, gdy prace wykopaliskowe w Megiddo doprowadziły do odkrycia fragmentu steli z kartuszami Szeszonka. Takie stele władcy egipscy wznosili zazwyczaj w miejscach podbitych w celu upamiętnienia swych zwycięstw. Podobne zostały znalezione m.in. w Bet Szean, Byblos i w Tyrze. ${ }^{46}$ Stela z Megiddo i napis w Karnaku wskazują, że miasto zostało zajęte przez Szeszonka, co nie musi oznaczać jego zniszczenia - mogło się poddać Egipcjanom bez walki. Gdyby faraon zniszczył Megiddo, prawdopodobnie nie postawiłby tu steli zwycięstwa. ${ }^{47}$

Poza źródłami egipskimi nazwa „Megiddo” w nowej formie pojawia się na glinianej tabliczce z Aszur, zawierającej zapisaną pismem klinowym królewską inskrypcję Asarhaddona z 679 r. p.n.e. Tekst wspomina gubernatora Magiddu; ${ }^{48}$ miasto było już od 734 r. p.n.e. stolicą asyryjskiej prowincji utworzonej po podboju królestwa Izraela przez Tiglatpilesara III. ${ }^{49}$

45 S. B e n-D or Evi a n, Shishak's Karnak Relief-More than just Name-rings, w: S. B a r, D. K a h n, J. J. S h i r l e y (red.) Egypt, Canaan and Israel: History, Imperialism, Ideology and Literature. Proceedings of a Conference at the University of Haifa, 3-7 May 2009, Culture and History of the Ancient Near East, t. 52, Boston-Leiden 2011, s. 13.

46 Y. L e v i n, Did Pharaoh Sheshonq Attack Jerusalem? Biblical Archaeology Review 38(2012) nr 4, s.43-45, 48-52; D. U s s i s h k i n, Megiddo-Armageddon, s. 326-331.

47 I. Fin kels t e i n, D. Us s is h k i n, Back to Megiddo, s. 43.

48 The Open Richly Annotated Cuneiform Corpus; http:/oracc.museum.upenn. edu/rinap/cbd/qpn/M.html (dostęp: 7 III 2029).

49 M. Live r a n i, Nie tylko Biblia. Historia starożytnego Izraela, s. 160-162. 


\section{Ekspedycje archeologiczne w Tel Megiddo}

Starożytne Megiddo zostało zidentyfikowane w początkach XX w. Po długich sporach rozpoznano je ostatecznie we wznoszącym się na wysokość ok. 70 m ponad Doliną Jezreel wzgórzu Tell el-Mutesellim. ${ }^{50}$ Pierwsze wykopaliska w tym miejscu zostały przeprowadzone w latach 1903-1905 przez inżyniera Gotlieba Schumachera, reprezentującego Niemieckie Towarzystwo Studiów nad Palestyną. Ekspedycja ta wykonała w poprzek wzgórza (które okazało się starożytnym tellem) wykop o wymiarach 18 na $23 \mathrm{~m}$, przebiegający z północy na południe, oraz kilka mniejszych wgłębień w innych częściach terenu, rozpoznając siedem poziomów osadnictwa. ${ }^{51}$ Wśród odkrytych budowli Schumacher zidentyfikował m.in. dwa ,pałace” i znajdujące się pod nimi grobowce „królewskie” z okresu środkowego i późnego brązu (warstwa II i III). Z epoki żelaza, gdy Megiddo było izraelskim miastem, pochodzą odsłonięte przez tę ekspedycję monumentalne budowle opisywane jako świątynia (z macewami) i pałac (warstwa V). Jeszcze pod koniec lat dwudziestych XX w. Carl Watzinger określił czas ich powstania na IX w. p.n.e., a zatem na okres panowania władców Północnego Królestwa (Izraela) Omriego i Achaba. ${ }^{52}$ Jednym z najsłynniejszych znalezisk ekipy Schumachera była pieczęć jaspisowa przedstawiająca ryczącego lwa i zawierająca hebrajską inskrypcję: ,„[należy] do Szemy, sługi Jeroboama”. Szema był zapewne wysokim urzędnikiem albo na dworze Jeroboama I,

50 D. U s s i s h k i n, Megiddo-Armageddon, s.22-23.

51 Wyniki tych prac zostały przedstawione w dwóch publikacjach: G. S c h u m a c h e r, Tell el-Mutesellim 1, Leipzig 1908; C. W a t z i n g e r, Tell el-Mutesellim 2, Leipzig 1929.

52 Tamże, s. 67-68. Opinię tę podzielają prowadzący tam obecnie badania uczeni z Uniwersytetu w Tel Awiwie, zob. np. D. Us s i s h k i n, Megiddo-Armageddon, s. 40; wcześniej pojawiały się inne propozycje datowania tych budowli, np. na czasy panowania Salomona, zob. np. A. N e g e v, Encyklopedia archeologiczna Ziemi Świętej, s. 287. 
który władał królestwem Izraela w X w. p.n.e., albo Jeroboama II, władcy tego królestwa w VIII w. p.n.e. ${ }^{53}$

Prace wykopaliskowe w Megiddo kontynuowane były od $1925 \mathrm{r}$. przez Instytut Orientalny Uniwersytetu w Chicago. Było to podjęte na dużą skalę przedsięwzięcie, zainicjowane przez egiptologa Jamesa H. Breasteda, którym kierowali kolejno Clarence Fisher, Philip Guy i Gordon Loud, prowadzone niemal do wybuchu II wojny światowej. ${ }^{54}$ Ekspedycja ta, mimo przyjętej początkowo błędnej metodologii badań, ${ }^{55}$ dokonała niezwykłych odkryć, uważanych dziś za jedne z najważniejszych na obszarze Izraela/Palestyny. Sprawiły one, że Tel Megiddo stało się jednym z kluczowych stanowisk archeologii biblijnej. Ekipa Instytutu Orientalnego zidentyfikowała w Megiddo dwadzieścia głównych poziomów osadnictwa, datowanych od VI tysiąclecia (neolit, chalkolit) do V w. p.n.e. Najważniejsze odkrycia

53 Pieczęć tę Schumacher wysłał do Konstantynopola, tam trafiła ona do prywatnej kolekcji sułtana. Dzisiaj miejsce jej przechowywania jest nieznane. I. Finkelste in, D. U s s ish ki n, Back to Megiddo, s. 29; D. U s s ish kin, Megiddo-Armageddon, s. 40.

${ }^{54}$ Rezultaty badań Instytutu Orientalnego zostały przedstawione w następujących publikacjach University of Chicago Press (w ramach serii Oriental Institute Publications): C.S. F i s h e r, The Excavation of Armageddon, Chicago 1929; P.L.O. G u y, New Light from Armageddon: Second Provisional Report (1927-29) on the Excavations at Megiddo in Palestine, Chicago 1931; H.G. M a y, Material Remains of the Megiddo Cult, Chicago 1935; R.S. L a m o n, The Megiddo Water System, Chicago 1935; P.L.O. G u y, Megiddo Tombs, Chicago 1938; R.S. L a m o n, G.M. S h i p t o n, Megiddo 1. Seasons of 1925-34: Strata I-V, Chicago 1939; G.M. S h i p t o n, Notes on the Megiddo Pottery of Strata VI-XX, Chicago 1939; G. L o u d, The Megiddo Ivories, Chicago 1939; t e n ż e, Megiddo 2. Seasons of 1935-39: Text and Plates, Chicago 1948.

55 Pierwotnie celem Instytutu Orientalnego było zdejmowanie, jedna po drugiej, każdej warstwy stanowiska aż do skalnego podłoża. Była to metoda niewykonalna ze względu na olbrzymi rozmiar obszaru badań; ponadto badanie jednorazowo pojedynczej warstwy uniemożliwiało dokonanie właściwej oceny stratygrafii terenu. Ten poważny błąd metodologiczny stanowił przyczynę ogromnego zamieszania, które utrudniało prawidłową interpretację znalezisk. Kiedy stało się to oczywiste, badacze skoncentrowali swoje wysiłki na wybranych obszarach tellu; zob. I. F i n kelste in, D. Us s i sh ki n, Back to Megiddo, s. 30. 
ekspedycji chicagowskiej to m.in. pozostałości konstrukcji zidentyfikowanej jako sanktuarium z wczesnego brązu (lata ok. 3400-3000 p.n.e.), Okrągły Ołtarz - „wyżyna” służąca składaniu ofiar, wzniesiona w okresie wczesnego brązu III, masywne kamienne mury (Walls 4045 i 4045A, warstwa XVIII), które interpretuje się jako część wielkich fortyfikacji lub mury oporowe mające związek z tzw. Wielką Świątynią, ${ }^{56}$ pałac datowany na epokę wczesnego brązu, trzy świątynie w kształcie wieży (Tower Temples I-III), pałac z okresu późnego brązu, Pałac Południowy z epoki żelaza (z czasów królów Izraela), jedno ze skrzydeł tzw. Bramy Salomona i kilka segmentów murów miejskich (City Wall 325) z przylegającymi do nich po obu stronach budynkami bramnymi. ${ }^{57}$

Kolejne badania archeologiczne prowadził w Megiddo Yigael Yadin z Uniwersytetu Hebrajskiego w Jerozolimie (w latach 1960, 1966, 1967 oraz w sezonie 1971/1972). Celem tych badań było wyjaśnienie skomplikowanych problemów stratygraficznych związanych z pozostałościami obiektów, szczególnie fortyfikacji, z okresu panowania króla Salomona. Wyniki badań budzą do dziś kontrowersje. ${ }^{58}$ Yadin miał nadzieję potwierdzić swoją teorię dotyczącą datowania bramy miejskiej z Megiddo na X w. p.n.e. W opublikowanym w 1958 r. artykule uczony ten udowadniał, że przekaz biblijny mówiący o wzniesieniu przez Salomona warowni w Hazor, Megiddo i Gezer $(1 \mathrm{Krl} 9,15)$ znajduje potwierdzenie w wynikach prowadzonych

56 G. L o u d, Megiddo 2, s. 66-70; D. U s s i s h k i n, Megiddo-Armageddon, s. 143-146.

57 Tamże, s. 69.

58 A. Z a r z e c k i - P e l e g, Yadin's Expedition to Megiddo. Final Report of the Archaeological Excavations (1960, 1966, 1967 and 1971/72 Seasons. Text, Hebrew University of Jerusalem, QEDEM 56/2016; Y. Y a d i n, New Light on Solomon's Megiddo, Biblical Archaeologist 23/1960, s. 62-68; t e n ż e, Megiddo of the Kings of Israel, Biblical Archaeologist 33/1970, s. 66-96; D. U s s i s h k i n, Megiddo-Armageddon, s. 73-78. Wyniki badań wszystkich ekspedycji przed 1992 r. przedstawiają publikacje: G.I. D a v i e s, Megiddo, Cambridge 1986 oraz A. K e m p i n s k y, Megiddo: A City State and Royal Centre in North Israel, Munich 1989. 
tam badań archeologicznych. ${ }^{59}$ Yadin uznał, że konstrukcja sześciokomorowej bramy w Megiddo powstała w mieście Salomona i jest współczesna podobnym bramom w Gezer i Hazor. Według niego ta sama brama była następnie użytkowana w okresie panowania królów Izraela, kiedy to została połączona z nową solidną ścianą, która zastąpiła wcześniejszą ścianę kazamatową. ${ }^{60}$ Hipoteza ta została podważona przez D. Ussishkina oraz I. Finkelsteina, a także przez innych uczonych, którzy datują tę bramę na IX w. p.n.e. ${ }^{61}$

Prace wykopaliskowe w Megiddo zostały podjęte ponownie przez Uniwersytet w Tel Awiwie we współpracy z Uniwersytetem Stanowym w Pensylwanii, pod kierownictwem Israela Finkelsteina i Dawida Ussishkina oraz Barucha Halperna. Prace te, mające na celu długoterminowe, systematyczne badania Tel Megiddo, rozpoczęły się od dwóch krótkich ekspedycji w 1992 i 1993 r. Począwszy od pierwszego pełnego sezonu wykopaliskowego, w 1994 r., badania prowadzone są co dwa lata, ${ }^{62}$ obejmując stopniowo następujące obszary:

59 Y. Ya d i n, Solomon's City Wall and Gate at Gezer, Israel Exploration Journal 8/1958, s. 80-86.

${ }^{60}$ Te n ż e, A Rejoinder, Bulletin of the American Schools of Oriental Research 239/1980, s. 19-23.

61 D. U s s i s h k i n, Was the 'Solomonic' City Gate at Megiddo Built by King Solomon? Bulletin of the American Schools of Oriental Research 239/1980, s. 1-18; t e n ż e, Megiddo-Armageddon, s. 321 i nast.; dyskusję i prezentowane argumenty zestawiła V. F a r g o, Scholars' Corner: Is the Solomonic City Gate at Megiddo Really Solomonic? Biblical Archaeology Review 9(1983) nr 5, s. 8, 10, 12-13. Zob. też P. B r i k s, Megiddo-perta archeologii biblijnej, Collectanea Theologica 74/2004, S. 5-17.

62 Rezultaty tych badań publikowane są w tomach będących kontynuacją publikacji podsumowujących wyniki prac prowadzonych przez Uniwersytet w Chicago. Dotychczas ukazały się następujące wydania: I. F i n k e l s t e i n, D. U s s i s h k i n, B. H a 1 p e r $n$ (red.), Megiddo III: The 1992-1996 Seasons, Monographs of the Institute of Archaeology of Tel Aviv University 18, t. I-II, Tel Aviv 2000; c i ż (red.), Megiddo IV: The 1998-2000 Seasons, Monographs of the Institute of Archaeology of Tel Aviv University 24, t. I-II, Tel Aviv 2006; I. F i n k e 1 s t e i n, D. U s s i s h k i n, E.H. C 1 i n e (red.), Megiddo V: The 2004-2008 Seasons, Monographs of the Institute of Archaeology of Tel Aviv University 31, t. I-III, Winona Lake 2013; w przygotowaniu jest kolejny tom: I. F in kels te i n, E. H. Clin e, M. A. S. M a r t in 
- Obszar F - znajduje się na dolnym tarasie, zawiera pozostałości ziemnego wału z okresu środkowego brązu, domów mieszkalnych z epoki późnego brązu I oraz z epoki żelaza I, a także monumentalnego budynku z okresu późnego brązu II;

- Obszar $\mathrm{G}$ - z bramą miejską z epoki późnego brązu, odkrytą przez zespół Uniwersytetu w Chicago (obszar AA);

- Obszar H - w północno -zachodniej krawędzi wzgórza; badanie koncentrowało się tu na określeniu związku między pałacami asyryjskimi, warstwą IVA zawierającą ślady zniszczeń oraz stratygrafią epoki żelaza;

- Obszar J - tutaj celem było ponowne przebadanie świątyń z wczesnej epoki brązu, odkrytych przez ekspedycję Uniwersytetu w Chicago w obszarze BB;

- Obszar K - znajduje się w południowo-wschodnim skraju tellu, zawiera pozostałości budynków mieszkalnych epoki żelaza I-II;

- Obszar L - tutaj ponownie przebadano pałac 6000, odsłonięty przez Y. Yadina i ,północne stajnie” częściowo odkryte przez zespół Uniwersytetu w Chicago;

- Obszar M-mieści się w centrum tellu, w okolicach wielkiego rowu biegnącego wzdłuż osi północ - południe, wykopanego przed laty przez G. Schumachera; prace na tym obszarze podjęto w celu ponownego zbadania monumentalnego grobowca komnatowego oraz budowli nazwanej przez jej odkrywcę Nordburgiem;

- Obszar N - znajduje się w północno- zachodniej części wzgórza i zawiera pozostałości budowli począwszy od epoki środkowego brązu III po późną epokę brązu I; ${ }^{63}$

(red.), Megiddo VI: The 2010-2014 Seasons, w serii Monographs of the Institute of Archaeology of Tel Aviv University. Zwięzłe informacje na temat najważniejszych odkryć dostępne są także na stronie internetowej ekspedycji: https://megiddoexpedition.wordpress.com/tel-aviv-university-excavations/; https://megiddoexpedition. wordpress.com/revelations-from-megiddo/ (dostęp: 17 III 2019).

${ }_{63}$ I. Finkels te i n, D. Us s is h k i n, B. H a l p e r n, hasło Megiddo, w: E. S te r n (red.), The New Encyclopedia of Archaeological Excavations in the 
- Obszar P - w północnej części wzgórza - prace zostały tu podjęte z inicjatywy izraelskiego Zarządu Ochrony Przyrody i Parków Narodowych;

- Obszar Q - położony w południowej części tellu, odkryto tu pozostałości pochodzące z okresu późnego brązu III, duży budynek z epoki żelaza IIA oraz warstwę zawierającą ślady zniszczeń z okresu późnego żelaza I; ${ }^{64}$

- Obszar S - w północnej części tellu, zawiera pozostałości monumentalnej struktury $\mathrm{z}$ epoki środkowego brązu;

- Obszar X - położony po zachodniej stronie wzgórza, otwarty w sezonie 2016, zawiera pozostałości konstrukcji pochodzących z VIII i VII w. p.n.e. (późne żelazo II; warstwy III-II). ${ }^{65}$ Dotychczasowe prace wykopaliskowe pozwoliły na ustalenie stratyfikacji Tel Megiddo, która przedstawia tabela $1 .{ }^{66}$

Holy Land, Israel Exploration Society, Jerusalem, Biblical Archaeology Society, Washington, DC 2008, s. 24-36. W trakcie tych badań przyjęto podwójny system określania stratygrafii: w każdym obszarze lokalne warstwy zostały oznaczone jako „poziomy” (level), litera oznaczająca obszar używana jest jako przedrostek dla numeru poziomu, np. Poziom K-3 (Level K-3) w obszarze K.W każdym obszarze poziomy są liczone od góry do dołu, z wyjątkiem obszaru J, gdzie lokalne warunki spowodowały zastosowanie odwrotnej numeracji. W ogólnej stratygrafii terenu zastosowano system numeracji warstw Chicago Expedition, np. Warstwa XII (Stratum XII).

64 D. U s s i s h k i n, Megiddo-Armageddon, s.79-89.

65 Wyniki badań z obszaru X jeszcze nie zostały opublikowane; informacja pochodzi z prezentacji przedstawionej przez Israela Finkelsteina na Uniwersytecie w Tel Awiwie w listopadzie 2016 r.

66 Podaję za: D. Us s is h k i n, Megiddo-Armageddon, s. 15; zob. I. F in kelste in, D. Us s is h k i n, B. H a l p e r n, hasło Megiddo, w: The New Encyclopedia of Archaeological Excavations in the Holy Land. Inne propozycje odnośnie stratyfikacji podają np. Y. A h a ro n i, The Stratyfication of Israelite Megiddo, Journal of Near Eastern Studies 3/1972, s. 302-311; Y. Y a d i n, A Note on the Stratigraphy of Israelite Megiddo, Journal of Near Eastern Studies 32/1973, s. 330, zob. też P. B r i k s, Podręczny stownik hebrajsko-polski i aramejsko-polski Starego Testamentu, s. 8. 
Tab. 1. Stratyfikacja stanowisk wykopaliskowych w Tel Megiddo

\begin{tabular}{|c|c|c|c|c|}
\hline \begin{tabular}{|l} 
Warstwa \\
(stratum of \\
mount)
\end{tabular} & \begin{tabular}{|l} 
Poziom \\
(level in \\
main areas)
\end{tabular} & Okres & $\begin{array}{l}\text { Przybliżone } \\
\text { daty } \\
\text { graniczne } \\
\text { (p.n.e.) } \\
\end{array}$ & $\begin{array}{l}\text { Najważniejsze } \\
\text { odkryte } \\
\text { pozostałości }\end{array}$ \\
\hline XX & $\mathrm{J}-1$ & $\begin{array}{l}\text { neolit, chalkolit, } \\
\text { wczesny brąz IA }\end{array}$ & $5000-3400$ & $\begin{array}{l}\text { osada na } \\
\text { wschodnim } \\
\text { zboczu wzgórza }\end{array}$ \\
\hline XIX & $\mathrm{J}-2$ & wczesny brąz IB & $3400-3000$ & $\begin{array}{l}\text { świątynia z wy- } \\
\text { brukowanym } \\
\text { dziedzińcem }\end{array}$ \\
\hline XIX & $\mathrm{J}-3$ & wczesny brąz IB & $3400-3000$ & świątynia 4050 \\
\hline XVIII & J-4 & wczesny brąz IB & $3400-3000$ & $\begin{array}{l}\text { Wielka } \\
\text { Świątynia }\end{array}$ \\
\hline XVIII & $\mathrm{J}-4 \mathrm{a}$ & wczesny brąz IB & $3400-3000$ & $\begin{array}{l}\text { ponowne użyt- } \\
\text { kowanie Wiel- } \\
\text { kiej Świątyni }\end{array}$ \\
\hline- & - & wczesny brąz II & $3000-2800$ & $\begin{array}{l}\text { możliwy brak } \\
\text { osadnictwa }\end{array}$ \\
\hline XVII -XVI & J-5; J-6b-a & wczesny brąz III & $2800-2400$ & $\begin{array}{l}\text { Okrągły Ołtarz, } \\
\text { osadnictwo }\end{array}$ \\
\hline $\mathrm{XV}$ & $\mathrm{J}-7$ & okres przejściowy & $2400-2000$ & $\begin{array}{l}\text { świątynie } \\
\text { na planie } \\
\text { megaronu }\end{array}$ \\
\hline XIV & $\mathrm{J}-8$ & okres przejściowy & $2400-2000$ & $\begin{array}{l}\text { skromne } \\
\text { osadnictwo }\end{array}$ \\
\hline XIII $-\mathrm{X}$ & F-12,11;M-8 & $\begin{array}{l}\text { środkowy brąz } \\
\text { I-II }\end{array}$ & $2000-1550$ & $\begin{array}{l}\text { kananejskie } \\
\text { miasto-państwo }\end{array}$ \\
\hline IX & F-10; M-7 & późny brąz I & $1550-1400$ & $\begin{array}{l}\text { kananejskie } \\
\text { miasto-państwo }\end{array}$ \\
\hline VIII - VIIA & $\begin{array}{l}\text { F-9,8,7; } \\
\text { K-8,7,6; M-6 }\end{array}$ & $\begin{array}{l}\text { późny brąz } \\
\text { II-IIIA-B }\end{array}$ & $1400-1130$ & $\begin{array}{l}\text { kananejskie } \\
\text { miasto-państwo }\end{array}$ \\
\hline VIB & $\begin{array}{l}\text { F-6; H-10; } \\
\text { K-5; M-5 }\end{array}$ & żelazo I & $\begin{array}{l}1130- \\
-1020 / 950\end{array}$ & $\begin{array}{l}\text { miasto } \\
\text { kananejskie }\end{array}$ \\
\hline VIA & $\begin{array}{l}\text { F-5; H-9; } \\
\text { K-4; L-5; } \\
\text { M-4 }\end{array}$ & żelazo I & $\begin{array}{l}130- \\
-1020 / 950\end{array}$ & $\begin{array}{l}\text { miasto } \\
\text { kananejskie }\end{array}$ \\
\hline
\end{tabular}




\begin{tabular}{|l|l|l|l|l|}
\hline $\begin{array}{l}\text { Warstwa } \\
\text { stratum of } \\
\text { mount })\end{array}$ & $\begin{array}{l}\text { Poziom } \\
\text { (level in } \\
\text { main areas) }\end{array}$ & Okres & $\begin{array}{l}\text { Przybliżone } \\
\text { daty } \\
\text { graniczne } \\
\text { (p.n.e.) }\end{array}$ & $\begin{array}{l}\text { Najważniejsze } \\
\text { odkryte } \\
\text { pozostałości }\end{array}$ \\
\hline VB & $\begin{array}{l}\text { H-8,7,6; K-3; } \\
\text { L-4 }\end{array}$ & $\begin{array}{l}\text { wczesny okres } \\
\text { żelaza IIA }\end{array}$ & $\begin{array}{l}970 / 950-900 \\
\text { osadnictwo } \\
\text { w okresie pano- } \\
\text { wania Dawida } \\
\text { i Salomona }\end{array}$ \\
\hline VA - IVB & H-5; K-2; L-3 & $\begin{array}{l}\text { późny okres } \\
\text { żelaza IIA }\end{array}$ & $\begin{array}{l}\text { ośrodek ad- } \\
\text { ministracyjny } \\
\text { w królestwie } \\
\text { północnym } \\
\text { (Izraela) }\end{array}$ \\
\hline IVA & $\begin{array}{l}\text { H-4,3; K-1; } \\
\text { L-2 }\end{array}$ & żelazo IIB & $830-732$ & $\begin{array}{l}\text { ośrodek } \\
\text { wojskowy } \\
\text { (militarny) } \\
\text { w królestwie } \\
\text { północnym } \\
\text { (Izraela) }\end{array}$ \\
\hline III - II & h-1; L-1 & żelazo IIC & $\begin{array}{l}\text { miasto } \\
\text { asyryjskie }\end{array}$ \\
\hline I & - & okres babiloński \\
okres perski & $600-330$ & $\begin{array}{l}\text { miasto egipskie } \\
\text { skromne } \\
\text { osadnictwo }\end{array}$ \\
\hline
\end{tabular}

\section{Dzieje Megiddo w świetle badań archeologicznych}

Początki osadnictwa

Znaleziskiem zawierającym najstarsze ślady ludzkiej bytności w Megiddo okazały się kości i narzędzia krzemienne z okresu neolitu oraz chalkolitu, które odkryto w grotach/jamach mieszczących się w skale macierzystej (warstwa XX, poziom J-1) ${ }^{67}$ na wschodnim zboczu wzgórza. Gordon Loud odsłonił tam także kilka konstrukcji zbudowanych z kamienia lub wykutych w skale, znaleziono również fragmenty ceramiki datowanej na okres neolitu II oraz glinianą figurkę interpretowaną jako przedstawienie bogini (podobne figurki

${ }^{67}$ G. L o u d, Megiddo II, s. 59. 
występują na stanowiskach archeologicznych kultury jarmuckiej) $\mathrm{z}$ tego samego okresu. ${ }^{68}$

\section{Epoka wczesnego brązu IA i IB}

W początkowej fazie epoki wczesnego brązu IA na wschodnim i południowo-wschodnim zboczu Tel Megiddo istniała duża osada (warstwa XX, poziom J-1). ${ }^{69}$ Odsłonięto tu m.in. pozostałości budynku z apsydą oraz pochówek zawierający charakterystyczną dla tego okresu ceramikę. ${ }^{70}$

Z okresu wczesnego brązu IB pochodzą ślady intensywnej religijnej aktywności w Megiddo. Badania dowiodły, że wzniesiono wówczas przynajmniej trzy świątynie wzdłuż krawędzi wierzchołka wzniesienia: drugą świątynię zbudowano na ruinach pierwszej, a trzecia, największa, którą oznaczono numerem 4050 (warstwa XIX, poziom J-3), powstała na pozostałościach drugiej (wczesna faza warstwy XIX, poziom J-2). ${ }^{71}$ Sanktuaria te mają wiele cech wspólnych, przypominających cechy innych świątyń odkrytych na terenie Izraela, pochodzących z okresu wczesnego brązu, a nawet wcześniejszych (jak chalkolityczna świątynia z 'En Gedi): każda z nich wzniesiona została na szczycie wzgórza, zawierała prostokątną salę z wejściem pośrodku jednej ze ścian, z ołtarzem zbudowanym wewnątrz naprzeciwko wejścia przy tylnej ścianie budynku; w środku sanktuarium mieściły się też kamienne lub ceglane (z cegły suszonej) ławy albo stoły osadzone w podłodze, służące do składania darów. ${ }^{72}$ Zdaniem D. Ussishkina w okresie wczesnego brązu IB kompleks świątynny w Megiddo był wyłącznie odosobnionym miejscem kultu

68 D. U s s i s h k i n, Megiddo - Armageddon, s. 106-107.

${ }^{69}$ E. B r a u n, Early Megiddo on the East Slope (The „Megiddo Stages”): A Report on the Early Occupation of the East Slope of Megiddo, Oriental Institute Publications 139, Chicago 2014, s. 39-49.

70 Tamże, s. 72-79.

${ }^{71}$ I. Finkelste in, D. U s s is h k i n, B. H a lpe r n, hasło Megiddo, w: The New Encyclopedia of Archaeological Excavations in the Holy Land.

72 S. G ą d e c k i, Archeologia biblijna, t. 1, Gniezno 1994, s. 152-153. 
(regionalnym centrum kultowym), gdyż brak dowodów na istnienie tam współczesnego sanktuariom pałacu władcy czy akropolu, na którym zwykle wznoszono główne świątynie miasta. ${ }^{73}$

Z epoki wczesnego brązu IB pochodzi jedno z najważniejszych odkryć dokonanych w Megiddo - monumentalny kompleks świątynny z tzw. Wielką Świątynią, odsłonięty, jak poprzednie sanktuaria, w obszarze J (warstwa XVIII, poziom J-4). Bez wątpienia w obrębie tego obszaru znajdowała się strefa sacrum, przez wiele stuleci służąca celom kultowym. Najważniejsza część kompleksu (poziom J-4B) mieści w sobie pozostałości Wielkiej Świątyni z dwiema masywnymi równoległymi ścianami o grubości 3,5 m, w dolnej części wykonanymi z kamienia, w górnej - z dużych kwadratowych cegieł suszonych. Na północ od nich znajduje się sala świątynna, odkryta tylko w części - jej pozostałości pozwalają jednak wnioskować, że była ona dużym pomieszczeniem (ok. 9 na $30 \mathrm{~m}$ ), z czterema zestawami dwóch filarów podtrzymujących dach. Odkryto tu także fragmenty murów i dwóch długich, wąskich korytarzy, wzdłuż których zachowało się nagromadzenie kości zwierzęcych o grubości $25 \mathrm{~cm}$. Podobne skupisko kości znajdowało się po południowej stronie korytarzy oraz w pobliżu późniejszego, Okrągłego Ołtarza 4017. Są one niewątpliwie pozostałościami złożonych w ofierze zwierząt. ${ }^{74}$

Świątynia, której pozostałości odkryto na poziomie J-4B warstwy XVIII, została prawdopodobnie uszkodzona podczas poważnego trzęsienia ziemi, a następnie porzucona na kilka dekad. Poziom J-4A zachował ślady ponownego zajęcia świątyni, na krótko, wciąż we wczesnej epoce brązu IB. Wkrótce potem sanktuarium zostało opuszczone na kilkaset lat. We wczesnej epoce brązu II Megiddo prawdopodobnie nie było zamieszkane ani nie stanowiło ośrodka kultu. ${ }^{75}$

73 D. U s s i s h k i n, Megiddo-Armageddon, s. 136-139; zob. też M. J. A d a m s, Area J: Part III: The Main Sector of Area J, w: I. F i n k e l s t e i n, D. U s s i s h k i n, E. H. Clin e (red.), Megiddo V, t. I, s. 47-118.

74 I. F i n k el s t e i n, D. U s s i s h k i n, B. H a l p e r n, hasło Megiddo, w: The New Encyclopedia of Archaeological Excavations in the Holy Land.

75 D. U s s i s h k i n, Megiddo-Armageddon, s. 139. 
Epoka wczesnego brązu III

Reaktywowanie kultu oraz osadnictwa nastąpiło w Megiddo w początkach epoki wczesnego brązu III (warstwa XVII, poziom J-5 oraz warstwa XVI, poziom J-6). Główne miejsce kultu odnowione zostało w dawnej strefie sacrum, ale ograniczało się ono do dużego ołtarza (4017) otoczonego dziedzińcem, było nieduże i zostało włączone do większej osady, zdominowanej przez duży gmach publiczny, prawdopodobnie pałac władcy ${ }^{76}$ Najbardziej spektakularne znalezisko tego okresu - Okrągły Ołtarz (4017) - miał trzy stadia rozwoju: pierwsze w warstwie XVII (poziom J-5), gdy został wzniesiony z małych kamieni, a wąski dziedziniec wokół niego otoczono kamiennym murem; drugie w warstwie XVI (poziom J-6), gdy został zburzony i zastąpiony nowym, okrągłym, o wymiarach $8 \mathrm{~m}$ średnicy i 1,4 m wysokości; trzecie stadium rozpoznano w warstwie XV (poziom J-7), reprezentującej okres przejściowy, gdy ołtarz był użytkowany bez zmian. Podwyższenie to było rodzajem świętej „wyżyny”, służącej składaniu ofiar z dużych zwierząt, kapłani wchodzili na jego górną platformę po siedmiu stopniach, które zachowały się do dziś. Wokół ołtarza odnaleziono liczne fragmenty kości zwierząt ofiarnych oraz ceramiki kultowej, a także kilka glinianych figurek zwierząt. ${ }^{77}$

\section{Okres przejściowy między epoką wczesnego a epoką środkowego brązu}

W okresie przejściowym w Megiddo nastąpiły znaczące zmiany. Pozostałości wszystkich budowli z tego okresu wskazują na nowy typ konstrukcji, co świadczy zapewne o całkowitej reorganizacji struktury politycznej i religijnej miasta oraz o znaczącej przemianie kulturowej społeczności zamieszkującej Megiddo w tym czasie (II połowa

\footnotetext{
76 Tamże, s.140, 146-147.

77 D. U s s i s h k i n, Megiddo-Armageddon, s. 148-149; A. N e g e v, Encyklopedia archeologiczna Ziemi Świętej, s. 287.
} 
III tysiąclecia p.n.e.). ${ }^{78}$ Najbardziej charakterystyczne zmiany widoczne są w obrębie rozległego kompleksu kultowego, gdzie odsłonięto odbudowany Okrągły Ołtarz 4017 oraz trzy podobne do siebie (ale nie identyczne) świątynie wzniesione na planie megaronu (warstwa XV, poziom J-7). Każda z nich miała ganek/przedsionek prowadzący do wnętrza prostokątnego sanktuarium (o wymiarach 9 na $14 \mathrm{~m})$, którego dach wsparty był na dwóch kolumnach. ${ }^{79}$

\section{Epoka środkowego brązu}

W epoce środkowego brązu, począwszy od XX w. p.n.e., Megiddo rozrosło się znacznie, stając się jednym z głównych i największych miast-państw Kanaanu. Niewątpliwie było to następstwem jego powiązań z Egiptem, zapoczątkowanych w okresie Średniego Państwa (za panowania faraonów XII dynastii) i kontynuowanych aż do epoki późnego brązu. ${ }^{80}$ Strategiczne położenie Megiddo przy Via Maris, prowadzącej z Egiptu do zachodniej Azji, miało wpływ na intensywny rozwój miasta; kontrola nad nim była warunkiem egipskiej hegemonii w Kanaanie. Było ono nieprzerwanie zamieszkane od końca okresu przejściowego aż do późnego brązu, a w trakcie prac wykopaliskowych nie natrafiono na żadne ślady zniszczeń w tym okresie. ${ }^{81} U$ stóp wzniesienia, po jego północno-wschodniej stronie, powstało wówczas Dolne Miasto, które, podobnie jak położone na wzgórzu Górne Miasto, zostało ufortyfikowane masywnymi ziemnymi umocnieniami. Pozostałości środkowej epoki brązu znaleziono głównie w obrębie obszarów F i M. Dominującą konstrukcją pochodzącą z tego okresu w obszarze F jest skomplikowany ziemny nasyp (warstwa XII, poziom F-12), który stabilizował i chronił zbo-

78 M. J. A d a m s, Area J: Part III: The Main Sector of Area J, s. 95.

79 D. Us s i s h k i n, Megiddo-Armageddon, s.159.

80 D. B e n - T o r, Pharaoh in Canaan. The Untold Story, s. 27 i nast.; J.A. W i 1 s o n, The Egyptian Middle Kingdom at Megiddo, American Journal of Semitic Languages and Literatures 58/1941, s. 225-236.

81 D. U s s i s h k i n, Megiddo-Armageddon, s. 172. 
cze w dolnej części wzgórza. Wał został zbudowany z kilku warstw ziemi, a jego dolna część wspiera się na kamiennym umocnieniu. ${ }^{82}$ Poniżej tej konstrukcji odkryto najstarszą w Megiddo bramę miejską i kilka domostw (warstwa XIII). ${ }^{83}$ Brama ta składała się z dwóch wąskich przejść zbudowanych względem siebie pod kątem prostym i była niemożliwa do pokonania przez zaprzęg, dlatego niemal powszechnie przyjmuje się, że wzniesiono ją zanim upowszechniło się użycie rydwanów. ${ }^{84}$ Miasto rozpoznane w warstwie XI otoczone było kamiennym murem grubości ok. 1,5 m, który obecnie uważa się raczej za rdzeń wału ziemnego, ${ }^{85}$ miało też pałac władcy położony w pobliżu nowej, szerszej bramy miejskiej (w przeciwieństwie do poprzedniej bramy z łatwością mogły przez nią przejeżdżać zaprzęgi konne). ${ }^{86}$

W 2016 r. członkowie zespołu Megiddo Expedition dokonali niezwykłego odkrycia: odsłonili sąsiadującą z pałacem władcy, wspaniałą i nietkniętą, liczącą 3600 lat komorę grobową (Tomb 16/H/50). Znajdowały się w niej trzy szkielety z pełnym, kosztownym wyposażeniem, m.in. złota, srebrna i brązowa biżuteria, kość słoniowa, naczynia pochodzenia cypryjskiego oraz egipskiego i kości zwierząt ofiarnych. Ze względu na monumentalność struktury, bogactwo wyposażenia oraz położenie w pobliżu pałacu królewskiego Israel Finkelstein uważa pochówek za grób królewski i na podstawie ceramiki datuje go na późny okres środkowej epoki brązu (1700-1600 r. p.n.e.), kiedy kananejskie Megiddo znajdowało się u szczytu potęgi, zanim rządząca tu dynastia upadła pod naporem egipskiej armii Totmesa III. ${ }^{87} \mathrm{Z}$ okresu środkowego brązu pochodzą także

82 I. F i n ke ls t e i n, D. U s s i s h k i n, B. H a l p e r n, hasło Megiddo, w: The New Encyclopedia of Archaeological Excavations in the Holy Land.

83 G. L o u d, Megiddo II, s. 6-7.

84 D. Us s i s h k i n, Megiddo-Armageddon, s.183.

85 Tamże, s.188.

86 A. N e g e v, Encyklopedia archeologiczna Ziemi Świętej, s. 288.

87 Wyniki badań tego grobowca są w trakcie opracowywania i nie zostały jeszcze opublikowane; dane podaję według prezentacji pt. Megiddo 2016. A Summary, przygotowanej przez I. Finkelsteina (udostępnionej mi przez autora), przestawionej przez niego na Uniwersytecie w Tel Awiwie w listopadzie 2016 r. Podstawowe 
pochówki odkryte w południowo-wschodnim zboczu wzniesienia, zawierające m.in. szkielety dzieci umieszczone w dużych naczyniach ceramicznych. ${ }^{88} \mathrm{~W}$ okresie tym nadal użytkowano święty obszar z wczesnej epoki brązu, szczególnie Okrągły Ołtarz (bamah) i co najmniej jedną z sąsiednich świątyń. Nowy budynek świątynny (świątynia 2048) powstał następnie jeszcze w tej epoce. ${ }^{89}$ Po obu stronach wejścia do tego sanktuarium odsłonięto dwie masywne wieże, ${ }^{90}$ jego mury miały ok. 3,5 m grubości, musiały się zatem wznosić na znaczną wysokość. Świątynia 2048 miała kształt dużego prostokątnego budynku o długości ponad $20 \mathrm{~m}$ i szerokości ponad $15 \mathrm{~m}$, z niszą umieszczoną w tylnej ścianie. Budowla została zniszczona wkrótce po powstaniu, a następnie powyżej jej fundamentów wzniesiono podobne sanktuarium (Tower Temple II).

informacje można uzyskać w następujących artykułach (i posterze): M. S. C r a $\mathrm{d}$ i c, Embodiments of Death: The Funerary Sequence and Commemoration in the Bronze Age Levant, Bulletin of the American Schools of Oriental Research 377/2017, s. 219-248; R. S. H o m s h e r, New Dimensions in Digital Documentation: Tomb 50 at Tel Megiddo, Poster presented at the Annual Meetings of The American Schools of Oriental Research, San Antonio, TX, November 2016; S. D e W it t P f i s t e r, A Royal Tomb at Biblical Armageddon?; https://www.biblicalarchaeology.org/daily/ biblical-sites-places/biblical-archaeology-sites/royal-tomb-biblical-armageddon-megiddo-expedition/ (dostęp: 21 III 2019); Ph. B o h s t r ö m, Exclusive: Royal Burial in Ancient Canaan May Shed New Light on Biblical City, National Geographic, march 2018; https://news.nationalgeographic.com/2018/03/megiddo-armageddon-dna-royal-burial-canaan-archaeology/ (dostęp: 22 III 2019).

88 G. S c h u m a c h e r, Tell El-Mutesellim I, s. 25.

89 Dyskusyjne są kwestie chronologiczne; świątynia 2048 bywa przypisywana do warstw XI-X, a nawet XII. G. L o u d umieszcza ją w warstwie VIII, zob. t e n ż e, Megiddo II, s. 102-104; zob. D. U s s i s h k i n, Megiddo-Armageddon, s. 207-216.

90 Podobną świątynię, pochodzącą z tego samego okresu, odnaleziono w Sychem; tego typu budowle nazwano tower temple (migdal) (B. M a z a r, hasło Migdal, w: Encyclopaedia Biblica, t. IV, Jerusalem 1962) lub fortress temple (I. F i n k e 1 s t e i n, D. U s s is h k i n, Back to Megiddo, s. 31). 
Późna epoka brązu

Późna epoka brązu rozpoczęła się ok. 1550 r. p.n.e., co zbiega się z początkami nowego Państwa w Egipcie i panowania tam XVIII dynastii. Jej założyciel, faraon Ahmose, wypędził Hyksosów, zjednoczył państwo i na długie lata przywrócił dominację Egiptu w Kanaanie. Hegemonia ta została wzmocniona, gdy Totmes III pokonał koalicję władców kananejskich miast-państw w bitwie pod Megiddo (ok. 1457 r. p.n.e.). W następstwie tej klęski Kanaan stał się prowincją egipską, której gubernator mógł mieszkać w Megiddo. ${ }^{91}$ Co istotne, badania archeologiczne nie wykazały żadnych pozostałości zniszczenia miasta w tym czasie. Brak także wskazówek co do destrukcji Megiddo w historii tej kampanii zaprezentowanej szczegółowo na reliefie znajdującym się w świątyni Amona w Karnaku. ${ }^{92}$ Być może, unikając strat, mieszkańcy ostatecznie sami się poddali. ${ }^{93}$ Po zajęciu Megiddo przez Egipcjan pałac ${ }^{94}$ w północnej części miasta został powiększony (długość ok. 46 m, grubość murów ok. 1,8 m; warstwy VIII-VII). Budowla miała duży dziedziniec wewnętrzny, a w jednym z pomieszczeń pałacowych odkryto łazienkę z umywalką oraz podłogą pokrytą muszlami osadzonymi w wapiennej zaprawie. ${ }^{95}$ Tuż przy pałacu przebudowano bramę miejską, wznosząc nowy budynek bramny, zawierający cztery pomieszczenia znajdujące się wzdłuż przejścia wiodącego na znajdujący się za bramą utwardzony plac. Główną świątynią Megiddo w epoce późnego brązu (warstwy VIII-VII) mogła być tzw. Tower Temple II (wzniesiona na miejscu

91 Zob. tamże, s. 6.

92 W.H. S h e a, The Conquest of Sharuhen and Megiddo Reconsidered, Israel Exploration Journal 29 /1979, s. 1-5.

93 I. F in ke ls t e i n, D. U s s is h k i n, Back to Megiddo, s.32; D. U s s is h k i n, Megiddo-Armageddon, s. 234.

94 Pałac ten mógł być siedzibą egipskiego gubernatora, jak wcześniej sugerował Finkelstein, lub kananejskiego władcy uznającego zwierzchnictwo Egiptu, jak chce Ussishkin; I. F i n k e l s t e i n, D. U s s i s h k i n, Back to Megiddo, s. 32; D. Us s i s h k i n, Megiddo-Armageddon, s. 245-246.

95 I. Fin kels te i n, D. Us s is h k i n, Back to Megiddo, s. 32. 
zburzonej Tower Temple I), wówczas najwyższy i najbardziej znaczący budynek w mieście, współczesny pałacowi i sąsiadującej z nim bramie miejskiej. ${ }^{96}$

Na późną epokę brązu można również datować znalezioną w Megiddo zapisaną pismem klinowym, tabliczkę zawierającą fragmenty mezopotamskiej epopei o Gilgameszu. Badanie paleograficzne wykazało podobieństwo znajdujących się na niej znaków pisma do tych, które występują na tabliczkach z Amarny. Istnieje duże prawdopodobieństwo, że została ona zapisana w Megiddo. Daje to uczonym nadzieję, że gdzieś na tym stanowisku archeologicznym może się znajdować archiwum tabliczek klinowych, jakiego nigdy jeszcze nie znaleziono w Izraelu. ${ }^{97} \mathrm{Z}$ tego okresu pochodzi wspomniana już korespondencja amarneńska, w skład której wchodziło m.in. sześć tabliczek adresowanych do faraona, podpisanych przez króla Megiddo Biridiję.

W pierwszej połowie XII w. p.n.e., za panowania Ramzesa III, Megiddo oraz położone w jego pobliżu miasto Bet Szean stanowiły centra egipskiej dominacji w północnym Kanaanie. ${ }^{98} \mathrm{Z}$ tego okresu pochodzi zbiór prawie dwustu bogato zdobionych płytek z kości słoniowej, odkrytych w jednym z pomieszczeń pałacu władcy Megiddo (warstwa VIIA). ${ }^{99}$ Koniec egipskiej hegemonii na obszarze Kanaanu nastąpił nie prędzej niż ok. 1130 r. p.n.e., gdyż tak datowana jest znaleziona w Megiddo baza statuetki Ramzesa VI, która według D. Ussishkina pierwotnie znajdowała się w głównej świątyni miasta w tym okresie (Tower Temple II). Główne budowle Megiddo (pałac, świątynia) zostały zniszczone w II połowie XII w. p.n.e. zapewne przez Ludy Morza, których pojawienie się skutkowało upadkiem

96 D. U s s is h k i n, Megiddo-Armageddon, s. 213; S. G ą d e c k i, Archeologia biblijna, s. 221-222.

97 I. F i n k e l s t e i n, D. U s s i s h k i n, Back to Megiddo, s. 33.

98 D. B e n-To r, Pharaoh in Canaan. The Untold Story, s. 93; I. S i n g e r, The Political Status of Megiddo VIIA, Journal of the Institute of Archaeology of TAU 15-16, Tel Aviv 1988-1989, s.101-112.

99 D. U s s i s h k i n, Megiddo-Armageddon, s. 253 i nast. 
kananejskich miast - państw pozostających pod kontrolą Egiptu od ponad trzech stuleci. ${ }^{100}$

\section{Epoka żelaza}

W miejsce zburzonej świątyni z epoki późnego brązu w Megiddo wzniesiono następnie, już w epoce żelaza I, podobną do niej Tower Temple III. ${ }^{101}$ Świątynię tę, wraz z większą częścią miasta reprezentowanego przez warstwę VI A, strawił pod koniec XI lub na początku $\mathrm{X}$ w. p.n.e. wielki pożar. Taki był tragiczny koniec kananejskiego miasta i położonego w jego najwyższym punkcie świętego obszaru, który stanowił centrum kultowe Megiddo przez niemal trzy tysiące lat, począwszy od epoki neolitu, gdy istniało tu sanktuarium pod gołym niebem (warstwa XX, poziom J-1). D. Ussishkin podkreśla, że musiał to być to niezwykle ważny lokalny ośrodek kultu, skoro prace wykopaliskowe odsłoniły dwadzieścia kolejnych faz jego historii. Pierwsze sanktuarium w Megiddo mieściło się na wysokości 156,6 m n.p.m., ostatnie - na 162,4 m, a nagromadzone tu w ciągu tysiącleci pozostałości praktyk kultowych (np. kości zwierząt ofiarnych, popiół, fragmenty naczyń) miały grubość ok. $6 \mathrm{~m}^{102}$

Badania wykazały, że potężny pożar, który doprowadził do zniszczenia kananejskiego miasta Megiddo warstwy VIA, wydarzył się między 1020 a 950 r. p.n.e. ${ }^{103}$ Ustalenie okoliczności tej destrukcji stanowi przedmiot sporu; B. Mazar wskazuje na podboje króla Dawida, C. Watzinger - na wyprawę Szeszonka I, E. Cline oraz A. Kempinski - na trzęsienie ziemi. Na podstawie wyników najnowszych badań (m.in. datowania radiowęglowego) I. Finkelstein uważa, że

100 Tamże, s. 272-280.

${ }^{101}$ E. A r i e, The Iron Age I Pottery: Levels K-5 and K-4 and an Intra - Site Spatial Analysis of teh Pottery from Stratum VIA, w: I. F i n k e l s t e i n, D. U s s i s h k i n, B. H a l p e r n (red.), Megiddo IV, t. I, s. 191-298.

102 D. U s s i s h k i n, Megiddo-Armageddon, s. 200, 220.

103 A. Gil b o a, I. S h a r o n, E. B o a r e t t o, Radiocarbon Dating of the Iron Age Levels, w: I. F in kels t e i n, D. U s s is h k i n, E. H. C l in e (red.), Megiddo V, t. III, s. 1117-1127. 
dokonały jej plemiona izraelskie, które zdominowały w tym czasie Dolinę Jezreel. ${ }^{104}$ Zniszczenie warstwy VIA w Megiddo, według zwolenników tezy Finkelsteina, dostarcza dowodów na wcześniejsze fazy ekspansji Izraelitów, które umożliwiły ustanowienie Północnego Królestwa (Izraela). ${ }^{105} \mathrm{Na}$ zgliszczach kananejskiego miasta wkrótce wyrosła nowa osada, początkowo skromna i pozbawiona fortyfikacji. Jej mieszkańcy używali ceramiki charakterystycznej dla epoki żelaza II, byli zatem pierwszymi przedstawicielami plemion izraelskich w tym miejscu (warstwa VB). Zapoczątkowali oni nowy rozdział w dziejach Megiddo - miasta izraelskiego, które będzie tu istniało ok. 250 lat, aż do podboju praz asyryjskiego króla Tiglatpilesara III. ${ }^{106}$ W okresie późnego żelaza IIA (ok. 900-830 r. p.n.e.; warstwy VA-IVB) miasto było ośrodkiem administracyjnym, na terenie którego, poza domami mieszkalnymi, wzniesiono trzy budowle: Pałac Północny 6000 , Wschodni $338^{107}$ oraz Południowy 1723 . Ich tylne ściany zostały zbudowane wzdłuż krawędzi wzniesienia, natomiast fasady

${ }^{104}$ B. M a z a r, The Stratification of Tell Abu Huwam on the Bay of Acre, Bulletin of the American Schools of Oriental Research 124/1951, s. 21-25; C. W a t z in g e r, Tell el-Mutesellim 2, s. 58, 91; E. H. C 1 i n e, Whole Lotta Shakin' Going On: The Possible Destruction by Earthquake of Stratum VIA at Megiddo. w: I. F i n k e $1 \mathrm{~s} t \mathrm{e}$ i n, N. N a' a m a n (red.), The Fire Signals of Lachish, Studies in the Archaeology and History of the Iron Age in Honor of David Ussishkin, Winona Lake 2011, s. 55-70; A. K e m p in s k i, Megiddo: A City State and Royal Centre in North Israel, Münich 1989, s. 89-90; I. F i n k e 1 s t e i n, E. P i a s e t z k y, Radiocarbon Datingand the Late - Iron I in Nothern Canaan, Ugarit - Forschungen 39/2007, s. 247-260; I. F in ke ls te i n, Destructions: Megiddo as a case study, w: D.J. S c h 1 o e $\mathrm{n}$ (red.), Exploring the longue durée: essays in honor of Lawrence E. Stager, Winona Lake 2009, s.113-126.

${ }^{105}$ Dotychczasową dyskusję zestawił D. K r o u w e r, The Late Iron Age I Destruction of Megiddo: Stratum VIA, seminar paper, Tel Aviv University, Faculty of Humanities, Department of Archaeology and Ancient Near Eastern Cultures, Tel Aviv 2016.

${ }^{106}$ D. U s s i s h k i n, Megiddo - Armageddon, s. 316.

${ }^{107}$ Według I. Finkelsteina i A. Kleimanna budynek 338 należy do warstwy IVA; budynek ten mógł być głównym centrum administracyjnym miasta, por. A. K 1 e i m a n, I. F i n k e l s t e i n, The Date of Building 338 at Megiddo: Eppur Si Muove! Israel Exploration Journal 68/2017, s. 50-55. 
zwrócone były w stronę centrum miasta. Te trzy pałace zaliczane są do najwspanialszych budowli Północnego Królestwa (Izraela), a ich istnienie potwierdza szczególną rolę Megiddo w tym państwie. ${ }^{108}$ Poza nimi na terenie współczesnego im miasta odkryto m.in. domostwa, które zbudowano wzdłuż krawędzi tellu i połączono ze sobą w taki sposób, by utworzyły rodzaj linii fortyfikacyjnej. Po północnej stronie wzgórza odsłonięto dwukomorową bramę miejską. ${ }^{109}$ Najnowsze ustalenia wskazują, że warstwa VB reprezentuje Megiddo z czasów panowania Salomona. Dane archeologiczne ani nie wspierają treści przekazu biblijnego wzmiankującego Megiddo w kontekście działań Salomona (1Krl 4,12; 9,15), ${ }^{110}$ ani nie zaprzeczają jego wiarygodności. David Ussishkin zwraca uwagę, że w Pierwszej Księdze Królewskiej 9,15 mowa jest o tym, iż Salomon zbudował Megiddo, a nie - że je ufortyfikował czy wzniósł tu bramę miejską. Podobnie jak oddalone od niego o ok. $15 \mathrm{~km}$ Jizreel, stało się ono jednym z najważniejszych miast Królestwa Północnego za panowania Omrydów (I połowa IX w. p.n.e.). Wydaje się, że Megiddo było wówczas ośrodkiem administracyjnym, a miasto Jizreel - strategicznym. ${ }^{111}$

W tej epoce Megiddo było także ośrodkiem kultu. Prace wykopaliskowe ujawniły pozostałości działalności kultowej w południowo-wschodnim sektorze tellu: m.in. nieistniejącą już dziś ,świątynię z macewami" (Massebot Temple 340), ${ }^{112}$ kamienne ołtarze oraz kapliczki ceramiczne, a także kielichy, misy wotywne, stojaki, „rogate” ołtarze ceramiczne, żeńskie figurki oraz grzechotki o przeznaczeniu kultowym (głównie obszar Q, epoka żelaza I oraz IIA; warstwy VA-IVB). ${ }^{113}$ Zespół badaczy z Uniwersytetu w Tel Awiwie wskazuje

108 D. Us s is h k i n, Megiddo-Armageddon, s. 319.

${ }^{109}$ I. F i n k e 1 s t e i n, D. U s s i s h k i n, B. H a l p e r n, hasło Megiddo, w: The New Encyclopedia of Archaeological Excavations in the Holy Land.

110 Zob. tamże, s. 4, 11-12.

111 D. U s s i s h k i n, Megiddo-Armageddon, s. 332.

112 Tamże, s. 370 i nast.

113 A. K le i m a n, M. E. C o h e n, E. H a 11, R.S. H o m s he r, I. Fin ke 1 s t e i n, Cult Activity at Megiddo in the Iron Age New Evidence and a Long-Term Perspective, Zeitschrift des Deutschen Palästina Vereins 133(2017) nr 1, s. 24-52. 
na wyraźną różnicę w praktykach kultowych w Megiddo między kananejskim a izraelskim okresem funkcjonowania miasta: kult w późnej epoce brązu koncentrował się w jednej dużej, centralnej świątyni, natomiast kult publiczny w epoce żelaza I był rozproszony i potwierdzony został w trzech dodatkowych miejscach, położonych w południowo-wschodniej części miasta. Praktyki kultowe w czasach Omrydów odbywały się nie w monumentalnej świątyni, ale w niewielkich sanktuariach znajdujących się w pomieszczeniach budynków administracyjnych. Możliwe, że sytuacja ta odzwierciedla próbę wzmocnienia władzy centralnej w Królestwie Izraela. ${ }^{114}$

W epoce żelaza IIB (warstwa IVA) Megiddo stało się jednym z najważniejszych ośrodków militarnych Królestwa Izraela. W miejsce nieufortyfikowanego centrum administracyjnego z okresu żelaza IIA powstało miasto otoczone potężnym murem (City Wall 325), z prowadzącą do niego monumentalną bramą miejską znaną jako „brama Salomona”. W jego obrębie znajdowały się dwa rozległe kompleksy stajni, prawdopodobnie będące bazą dla rydwanów i koni (oraz żołnierzy) należących do armii Północnego Królestwa. Każdy z tych obiektów składał się z pomieszczenia $\mathrm{z}$ dwoma rzędami filarów pośrodku (zapewne podpierały one dach i przywiązywano do nich konie). ${ }^{115} \mathrm{~W}$ pobliżu stajni odkopano ogromny silos, używany, jak się wydaje, do przechowywania karmy dla dużej liczby koni. Po zachodniej stronie miasta wykopaliska odkryły wykuty w skale potężny system wodny, umożliwiający dostęp do zewnętrznego źródła, co zapewniało odpowiednią dla tak wielu zwierząt i ludzi ilość wody. ${ }^{116}$ System ten tworzyła wielka (o średnicy $5,5, \mathrm{~m}$ ) pionowa studnia ze spiralnymi schodami, prowadząca do poziomego, wiodącego do

114 Tamże, s. 42,46.

115 Wyczerpujące informacje o tych obiektach: N. Fran k li n, Entering the Arena: The Megiddo Stables Reconsidered, w: O. L i p s c hit s, Y. G a d ot, M. J. A d a m s (red.), Rethinking Israel. Studies in the History and Archaeology of Ancient Israel In Honor of Israel Finkelstein, Winona Lake 2017, s. 87-101.

116 N. Fra n k 1 i n, Relative and Absolute Chronology of Gallery 629 and the Megiddo Water System: A Reassement, w: I. F in kels t e i n, D. U s s is h k in, B. H a 1 p e r n (red.), Megiddo III, t. II, s. 515-523. 
źródła korytarza zakończonego schodami. ${ }^{117}$ Zmiana funkcji miasta spowodowała, że nie istniała już potrzeba wznoszenia czy utrzymywania pałaców, a ich pozostałości z poprzednich warstw, zwłaszcza doskonale obrobione bloki kamienne, były w tym czasie używane do wznoszenia nowych budynków o innym przeznaczeniu. Datowanie tych obiektów pozostaje wciąż przedmiotem sporów, jednak ostatnie badania wskazują na czasy panowania w Królestwie Izraela Joasza oraz jego syna Jeroboama II (I połowa VIII w. p.n.e.). ${ }^{118}$ Szczególnie dyskutowana była chronologia bramy miejskiej, która jest największym tego typu kompleksem w Megiddo, składającym się z wybrukowanej, szerokiej drogi, dwukomorowej bramy zewnętrznej, sześciokomorowej bramy wewnętrznej oraz łączącego je dziedzińca. Jak już wspomniano, w przeszłości wzniesienie tego obiektu łączono z działalnością króla Salomona, dziś jednak wiadomo, że nastąpiło to w czasach Omrydów. ${ }^{119} \mathrm{~W}$ pobliżu tej bramy zachowały się wąskie schody; cel ich budowy nie został wyjaśniony. ${ }^{120}$

Obiekty warstwy IVA przetrwały aż do podboju Megiddo przez Tiglatpilesara III w 732 r. p.n.e. Po tym wydarzeniu, którego świadectwem są ślady destrukcji części budynków mieszkalnych, stajnie były stopniowo opuszczane (podobnie też ocalałe domy), ale potężny mur miejski oraz system wodny pozostały nietknięte. ${ }^{121}$ Po zajęciu Królestwa Izraela przez Sargona II mieszkańcy podbitych terenów zostali deportowani, a ich miejsce zajęli osadnicy z innych regionów imperium. Megiddo zostało stolicą asyryjskiej prowincji - miasto odbudowano i zasiedlono na nowo. W tym asyryjskim mieście znajdowały się fortyfikacje, pałace gubernatora, budynki publiczne i mieszkalne, których pozostałości odsłonięto w trakcie wykopalisk (warstwy III-II). Częścią fortyfikacji stał się miejski mur obronny

117 S. G ą d e c k i, Archeologia biblijna, s. 268-269.

118 D. U s s is h k i n, Megiddo-Armageddon, s. 387 i nast.

119 Tamże, s. 399.

${ }^{120}$ N. Frank 1 i n, Area P, w: I. Fin ke ls te in, D. Us s is h k in, E. H. C 1 in e (red.), Megiddo V, t. I, s. 286-291.

${ }^{121}$ D. U s s i s h k i n, Megiddo-Armageddon, s. 389. 
z poprzedniej warstwy (IVA, City Wall 325), który rozbudowano. W miejsce zniszczonego kompleksu bramy miejskiej wzniesiono nowy, mniejszy obiekt. ${ }^{122}$ Po obu stronach bramy, w północnym sektorze miasta, częściowo na miejscu dawnych stajni, powstało kilka publicznych budowli. Spośród nich najważniejszy był pałac gubernatora, wzniesiony w stylu typowym dla współczesnej mu architektury asyryjskiej. ${ }^{123}$ Obiekt ten składał się właściwie z dwóch odrębnych budynków, z których każdy miał wewnętrzny, otwarty dziedziniec otoczony licznymi pomieszczeniami. ${ }^{124}$ Po zachodniej stronie miasta znajdował się będący wówczas wciąż w użytkowaniu system wodny. W jego pobliżu wzniesiono nowe, przestronne domy mieszkalne, położone przy dobrze rozplanowanych, przecinających się pod kątem prostym ulicach. ${ }^{125}$ Między domami prace wykopaliskowe odsłoniły sześć pochówków, w których użyto glinianych trumien w kształcie wanny. ${ }^{126}$

Po upadku imperium asyryjskiego faraon Necho II podjął wyprawę do północnej Syrii, nad którą chciał przejąć kontrolę wspierając resztki asyryjskiej armii i powstrzymując ekspansję babilońską. W 609 r. p.n.e. wojska egipskie przybyły do Megiddo. ${ }^{127}$ Wyprawę tę próbował tu zatrzymać król Judy Jozjasz, ${ }^{128}$ który, co bardzo

122 Tamże, s. 419-420.

${ }^{123}$ R. R e i c h, Palaces and Residencies In the Iron Age, w: A. K e m p i n s k i, R. R e i c h (red.), The Architecture of Ancient Israel; From the Prehistoric to the Persian Periods, Jerusalem 1992, s. 202-222.

${ }^{124}$ I. F i n k e l s t e i n, D. U s s i s h k i n, B. H a l p e r n, hasło Megiddo, w: The New Encyclopedia of Archaeological Excavations in the Holy Land.

125 A. N e g e v, Encyklopedia archeologiczna Ziemi Świętej, s. 288.

${ }^{126}$ Podobne trumny odkryto w północnej Mezopotamii, zob. D. U s s i s h k i n, Megiddo-Armageddon, s. 434.

${ }^{127}$ M. L i v e r a n i, Nie tylko Biblia. Historia starożytnego Izraela, s. 180-183, 194.

128 Jozjasz był jednym z najważniejszych władców Królestwa Judy; największym jego dokonaniem była reforma religijna, zmierzająca do centralizacji kultu Jahwe w świątyni jerozolimskiej, zob. np. N. N a' a m a n, The Kingdom of Judah under Josiah, Tel Aviv 18/1991, s. 122-128; M. L i ve r a n i, Nie tylko Biblia. Historia starożytnego Izraela, s. 185-194. 
prawdopodobne, chciał wykorzystać upadek Asyrii w celu wzmocnienia niezależności swego państwa, a nawet powiększenia jego terytorium. Jak opisano wyżej, konfrontacja zakończyła się klęską Jozjasza i jego śmiercią. Egipska kontrola nad Megiddo była w tym czasie bardzo krótka - dowodzone przez Necho wojska egipskie zostały wraz z resztkami armii asyryjskiej pokonane przez Nabuchodonozora II w bitwie pod Karkemisz w 605 r. p.n.e. ${ }^{129}$ Miasto, wraz z całym obszarem należącym poprzednio do Asyrii, przeszło pod władzę Babilonii. Był to koniec jego wielkości - od tej pory Megiddo nigdy już nie odgrywało ważnej roli i powoli się wyludniało. Ostatnia warstwa osadnicza tellu (warstwa I) datowana jest na okres babilońskiej oraz achemenidzkiej dominacji: od początków VI w. p.n.e. do końca epoki perskiej. ${ }^{130}$ Charakteryzowała się ona skromnymi zabudowaniami i brakiem fortyfikacji. Wielkie budowle poprzedniej epoki stopniowo popadały w ruinę; nawet system wodny, jeszcze przez jakiś czas używany, powoli wypełniał się różnymi zanieczyszczeniami, które w końcu zablokowały do niego dostęp. ${ }^{131}$

Jak już wspomniano, w pobliżu opuszczonego Megiddo w okresie rzymskim powstała nowa osada - Kefar 'Othnay, gdzie wykopaliska odsłoniły m.in. chrześcijańską salę modlitewną. W okolicy tej stacjonował najpierw II legion rzymski (Legio II Traiana), a po powstaniu Bar Kochby został tu umieszczony VI legion (Legio VI Ferrata). Od nazwy tego ostatniego miejscowość zaczęto określać mianem

${ }^{129}$ W 2016 r. ekspedycja Uniwersytetu w Tel Awiwie rozpoczęła prace wykopaliskowe w obszarze X, w wyniku których zbadano warstwy III-II (późne żelazo II). Osłonięto doskonale zachowane struktury pochodzące z VIII i VII w. p.n.e. oraz m.in. fragmenty ceramiki greckiej, która może wskazywać na obecność greckich najemników w Megiddo podczas ostatniej bytności egipskiej w tym mieście (pod koniec VII w. p.n.e.), a to z kolei może rzucić światło na dramatyczne wydarzenia z 609 r. p.n.e. Wyników badań jeszcze nie opublikowano; informacje podaję według prezentacji pt. Megiddo 2016. A Summary, przygotowanej przez I. Finkelsteina (udostępnionej mi przez autora), przestawionej przez niego na Uniwersytecie w Tel Awiwie w listopadzie 2016 r.

${ }^{130}$ R.S. L a m o n, G. M. S h i p t o n, Megiddo I, s. 88-91.

131 D. U s s i s h k i n, Megiddo-Armageddon, s. 440-441. 
Legio, a od IV w., po wycofaniu się wojska, miasto otrzymało nazwę Maximianopolis. ${ }^{132}$

Ewa RONOWSKA

Słowa kluczowe: Megiddo/Armageddon; Biblia; archeologia; etymologia Keywords: Megiddo/Armageddon; Bible; archeology; etymology

\section{Biblical Megiddo in the Light of Results of Archaeological Research Summary}

The starting point of the article is to explain the reasons why Megiddo was one of the most important Canaanite cities in the northern Palestine, as well as the presentation of scientific proposals explaining the etymology and meaning of its name. In this context, considerations regarding the Bible narration associated with Megiddo and references to it contained in extra-biblical sources are included. The second part of the article presents an outline of the history of archaeological research in Tel Megiddo, which is the starting point for presenting the history of biblical Megiddo in the light of the results of these studies. The article presents various, often contradictory, views of researchers on the history of Megiddo based primarily on the analysis of archaeological data, from the Neolithic, through the Early, Middle and Late Bronze Ages to the Iron Age.

132 Tamże, s. 442; A, N e g e v, Encyklopedia archeologiczna Ziemi Świętej, s. 262-263. 